Review

\title{
Applications of Liquid-Phase Microextraction in the Sample Preparation of Environmental Solid Samples
}

\section{Helena Prosen}

Faculty of Chemistry and Chemical Technology, University of Ljubljana, Aškerčeva 5, SI-1000 Ljubljana, Slovenia; E-Mail: helena.prosen@fkkt.uni-lj.si; Tel.: +386-1-2419-176; Fax: +386-1-2419-220

Received: 21 April 2014; in revised form: 19 May 2014 / Accepted: 21 May 2014 /

Published: 23 May 2014

\begin{abstract}
Solvent extraction remains one of the fundamental sample preparation techniques in the analysis of environmental solid samples, but organic solvents are toxic and environmentally harmful, therefore one of the possible greening directions is its miniaturization. The present review covers the relevant research from the field of application of microextraction to the sample preparation of environmental solid samples (soil, sediments, sewage sludge, dust etc.) published in the last decade. Several innovative liquid-phase microextraction (LPME) techniques that have emerged recently have also been applied as an aid in sample preparation of these samples: single-drop microextraction (SDME), hollow fiber-liquid phase microextraction (HF-LPME), dispersive liquid-liquid microextraction (DLLME). Besides the common organic solvents, surfactants and ionic liquids are also used. However, these techniques have to be combined with another technique to release the analytes from the solid sample into an aqueous solution. In the present review, the published methods were categorized into three groups: LPME in combination with a conventional solvent extraction; LPME in combination with an environmentally friendly extraction; LPME without previous extraction. The applicability of these approaches to the sample preparation for the determination of pollutants in solid environmental samples is discussed, with emphasis on their strengths, weak points and environmental impact.
\end{abstract}

Keywords: liquid-phase microextraction; SDME; HF-LPME; DLLME; environmental solid sample; soil; sediment 


\section{Introduction}

Solvent extraction (SE) remains one of the fundamental techniques employed prior to the analysis of the environmental contaminants in solid samples due to its high efficiency in transferring the compounds of interest from the frequently complex sample matrix into an analytical instrument-friendly solution. Procedures used to facilitate the transfer of analytes into the solvent are numerous: continuous extraction with a solvent at elevated temperatures (Soxhlet); mechanical or ultrasound shaking (USE); mixing of solid and solvent at elevated temperatures and pressure (pressurized liquid extraction-PLE); microwave heating and/or increased pressure (MWE); extraction with solvents with decreased viscosity, higher permeability, and higher diffusion rate, such as supercritical fluids (supercritical fluid extraction-SFE). While each of the above is a well established approach and has been demonstrated to be efficient for certain analytes, they are less advantageous for others, as has been shown in a number of critical reviews [1-3].

However, the main disadvantage of these techniques is the use of organic solvents. Only SFE is exempt from that, but is less widespread because of its high operating costs and complex method optimization [2]. Organic solvents are recognized as problematic for several reasons: most of them are toxic to living organisms and harmful to the environment, therefore special care has to taken for their proper disposal; moreover, they should be of high grade purity to avoid the contamination of extracts in trace analysis, and this alone significantly contributes to the high cost of analysis. These facts seem "a conflict of interest" in environmental analysis more than in any other area of analysis: analytical methods for the determination of environmental pollutants should not themselves contribute to the pollution.

To reduce its impact on the environment new developments in solvent extraction have gone in two separate directions: one is the search for more environmentally friendly solvents, the second one is miniaturization. An example of a greener solvent introduced in the environmental sample preparation is supercritical water extraction (SWE) or pressurized hot water extraction (PHWE): water at temperatures up to $650 \mathrm{~K}$ and sufficiently high pressure becomes less polar, less viscous and thus more applicable to the extraction of organic contaminants of lower polarity, but the disadvantages of its use are rather low extraction yields, difficulties with subsequent solvent evaporation and incompatibility with thermally unstable compounds [2,3]. Another example are ionic liquids (IL), which, although synthetic compounds, are considered more environmentally friendly because of their low volatility and lower toxicity compared to conventional organic solvents [2-4]. The third example is the employment of non-ionic surfactants in cloud-point extraction (CPE) or ionic surfactants in coacervative extraction (CAE) as the replacement for organic solvents [4]. Their advantages are low toxicity, low volatility and in some instances also increased biodegradability [5].

The subject of the present review is the other green direction in solvent extraction: miniaturization. Several innovative techniques have emerged, some less than a decade ago, that can be put under the umbrella of liquid-phase microextraction (LPME). The focus of the review is on the use of LPME approaches in the extraction of organic pollutants present in the solid and semi-solid environmental samples. Miniaturized solvent extractions are widely employed also to isolate different metal species in inorganic analysis, but the subject has already been covered in some excellent reviews [5-7]. To the best of our knowledge, there is currently no reviews dealing solely with the application of LPME to 
sample preparation of solid environmental samples, but there are several on the use of LPME techniques for aqueous environmental samples and the interested reader is encouraged to read them [8-23]. The emphasis of the present review is on the research published in the last decade; however, some older literature will be considered whenever necessary to facilitate the understanding of subsequent advances.

\section{Modes and Variations of Liquid-Phase Microextraction}

The common feature of numerous LPME variations is the use of at least one liquid solvent, usually organic, into which the analytes of interest are extracted. The other common feature is the small volume of this solvent, typically $1-100 \mu \mathrm{L}$. Figure 1 is a schematic representation of the most popular modes of LPME, judging from the number of publications, deliberately leaving out the numerous subvariants. Although there is a considerable confusion with the names and abbreviations for the variants of LPME (originally named solvent microextraction, SME [24]) in the literature [25], only the currently most frequently encountered name is used throughout this paper, which may or may not originate from the inventors of the technique.

Figure 1. Variants of liquid-phase microextraction (LPME) with the highest number of publications.

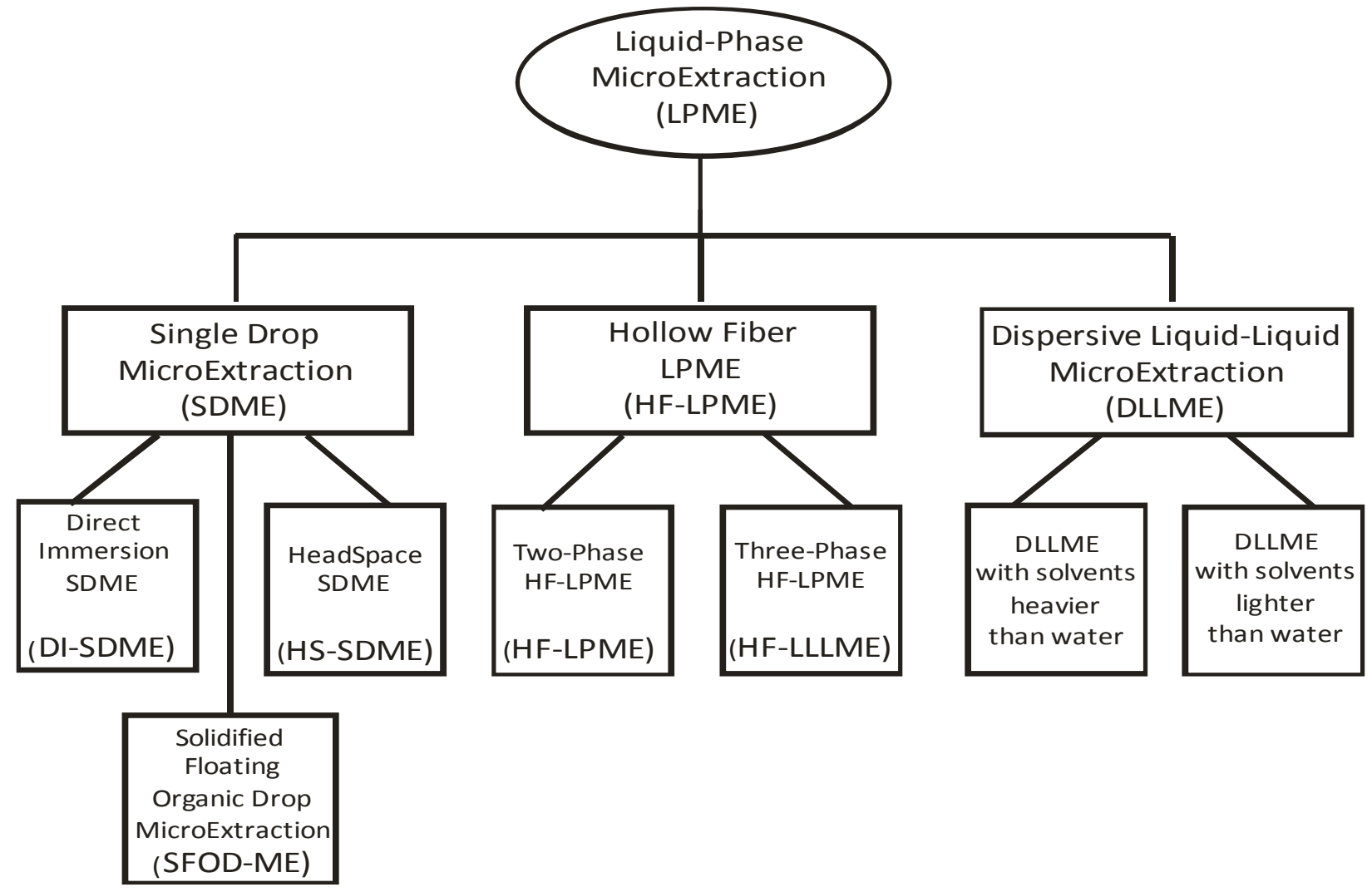

The three main approaches to LPME are single drop microextraction (SDME), hollow fiber liquid-phase microextraction (HF-LPME) and dispersive liquid-liquid microextraction (DLLME). SDME in its original form, first described by Jeannot and Cantwell in 1996 [24], is the simplest way to perform LPME. A drop of organic solvent is exposed for a certain time to the sample, then collected and subjected to the analysis. Usually, the drop is carefully expelled from and later retracted into the 
syringe used in gas chromatography to inject liquid samples. A drop directly exposed to the aqueous sample is named direct immersion SDME (DI-SDME), while it can be also exposed to the headspace above the sample (HS-SDME). Alternatively, organic solvent lighter than water can be dropped to the surface of aqueous sample, left for a certain time while stirring and later collected. The latter is rather difficult to perform with a microsyringe, therefore solidification of the drop at lower temperature and its collection by spatula was designed by Zanjani et al. [26] and named solidified floating organic drop microextraction (SFOD-ME).

The first application of hollow fibers (HF) for the analyte extraction from aqueous samples was published by Pedersen-Bjergaard and Rasmussen [27]. In fact, their method was hollow fiber liquid-liquid-liquid microextraction (HF-LLLME). In this technique, hollow fiber (usually polypropylene) constitutes a semi-permeable membrane, in which the pores are filled with a suitable organic solvent. In the fiber lumen, the same organic solvent may be present, in this case we speak of two-phase HF-LPME, developed by the same group [28] (also: HF(2)ME). Alternatively, a different immiscible solvent is present within the fiber lumen to allow for two equilibria for the analytes: between the water and solvent in the wall; between the solvent in the wall and in the lumen; constituting the three-phase HF-LPME (HF-LLLME or HF(3)ME).

Dispersive liquid-liquid microextraction (DLLME) is the newest addition to LPME variants, first described by Rezaee et al. in 2006 [29], but it has rapidly gained in popularity. A water-immiscible extraction solvent is rapidly injected into an aqueous sample together with a water-miscible disperser solvent, thus forming a very fine emulsion allowing for rapid transfer of analytes into the solvent. Solvent is subsequently separated from the sample by centrifugation.

Although these popular LPME techniques may bear some similarity, there are differences in terms of ease of optimization, ease of operation and extent of preliminary preparations, consumed time and amenability to automation. Table 1 addresses these issues, as well as some attractive modifications.

The main advantages of liquid-phase microextraction techniques are the exceptionally low consumption of organic solvents and their relative simplicity. By far the most simple is SDME, either by direct immersion or from the headspace. The instability of the drop at the tip of syringe has led researchers to propose new designs, e.g., a silicone ring at the tip of the syringe [30] or a Teflon ring design originally proposed by Ma and Cantwell in 1999 [31] to allow for back-extraction of polar compounds into an aqueous drop (liquid-liquid-liquid microextraction, LLLME). Hollow fiber-liquid phase microextraction is more cumbersome compared to SDME because of the need to prepare disposable hollow fibers, and dispersive liquid-liquid microextraction because of the need to separate the phases after the dispersion step. With extraction solvents heavier than water, a centrifugation step is needed to sediment the solvent on the bottom of a conical vial from where it is collected by a syringe; with extraction solvents lighter than water, solvent forms an upper layer and is difficult to collect by syringe only. Solidifying of the solvent (solidified floating organic drop, SFOD) is achieved by cooling the mixture in an ice bath, however this limits the choice of solvents to those with melting point of $10-30{ }^{\circ} \mathrm{C}$. To extend the choice of solvents, special extraction vessels that facilitate the collection of the upper layer have been designed [16,17,32]. An interesting approach is demulsification of the sample-solvent emulsion in an upside-down Pasteur pipette, achieved by adding a demulsifier solvent [33]. 
Table 1. Properties of LPME techniques [1,3,8-13,15-18,25,32].

\begin{tabular}{|c|c|c|c|c|c|c|c|c|}
\hline Technique & Solvent properties & $\begin{array}{l}\text { Solvent } \\
\text { volume }\end{array}$ & $\begin{array}{l}\text { Sample preparation; } \\
\text { other equipment }\end{array}$ & $\begin{array}{l}\text { Mixing/ } \\
\text { stirring } \\
\end{array}$ & Extraction time & $\begin{array}{l}\text { Typical } \\
\text { analytes }\end{array}$ & Automation & $\begin{array}{l}\text { Other considerations \& } \\
\text { modifications }\end{array}$ \\
\hline SDME & $\begin{array}{l}\text { immiscible with water; } \\
\text { usually GC-compatible } \\
\text { HS-SDME: low vapor pressure, } \\
\text { also water; } \\
\text { recent: ionic liquids }\end{array}$ & $1-8 \mu \mathrm{L}$ & $\begin{array}{l}\text { GC syringe } \\
\text { sample: filtration in DI- } \\
\text { SDME; adjustment of } \\
\text { ionic strength, } T\end{array}$ & $\begin{array}{l}\text { DI-SDME: up } \\
\text { to } 600 \mathrm{rpm} \\
\text { HS-SDME: } \\
\text { higher rates }\end{array}$ & $\begin{array}{l}\min .1-15 \mathrm{~min} \text {, } \\
\text { usually longer }\end{array}$ & $\begin{array}{l}\text { non-polar, } \\
\text { semi- } \\
\text { volatile or } \\
\text { volatile } \\
\text { (HS- } \\
\text { SDME) }\end{array}$ & $\begin{array}{l}\text { semi-automatic } \\
\text { in dynamic } \\
\text { mode; } \\
\text { continuous } \\
\text { flow ME } \\
\text { (CF-ME) [34] }\end{array}$ & $\begin{array}{l}\text { simple; ready-to-analyze extracts; } \\
\text { modifications: } \\
\text { dynamic mode possible in-needle } \\
\text { or in-syringe; } \\
\text { LLLME with back-extraction into } \\
\text { droplet of } 2 \text { nd immiscible solvent; } \\
\text { exhaustive extraction by multiple } \\
\text { HS-SDME [35] }\end{array}$ \\
\hline HF-LPME & $\begin{array}{l}\text { immiscible with water; } \\
\text { compatible with HF material; } \\
\text { low volatility \& viscosity, } \\
\text { e.g., toluene, } n \text {-octanol, also } \\
\text { di- } n \text {-hexyl ether } \\
\text { HF-LLLME: above valid for solvent } \\
\text { in the HF wall; in the HF lumen: } \\
\text { aqueous acceptor phase or ionic } \\
\text { liquid or immiscible organic solvent }\end{array}$ & $4-20 \mu \mathrm{L}$ & $\begin{array}{l}\text { small-diameter porous } \\
\text { tube (fiber), usually } \\
\text { polypropylene, one end } \\
\text { sealed, other attached to } \\
\text { syringe } \\
\text { sample: adjustment of } \\
\text { pH and ionic strength }\end{array}$ & $\begin{array}{l}\text { vigorous } \\
\text { stirring or } \\
\text { vibration, } \\
\text { microwaves }\end{array}$ & $\begin{array}{l}20-60 \mathrm{~min} \\
\text { (except for } \\
\text { dynamic HF- } \\
\text { LPME or EME) }\end{array}$ & $\begin{array}{l}\text { non-polar; } \\
\text { ionizable } \\
\text { (in HF- } \\
\text { LLLME) }\end{array}$ & $\begin{array}{l}\text { yes, with } \\
\text { autosampler; } \\
\text { dynamic HF- } \\
\text { LPME [36]; } \\
\text { still each fiber } \\
\text { manually } \\
\text { prepared }\end{array}$ & $\begin{array}{l}\text { applicable to »dirty« samples; } \\
\text { modifications: } \\
\text { dynamic HF-LPME [36]; } \\
\text { solvent-bar microextraction (SBE) } \\
\text { [37]; } \\
\text { air in HF wall with aqueous solvent } \\
\text { in lumen for volatile analytes [38] }\end{array}$ \\
\hline DLLME & $\begin{array}{l}\text { disperser solvent: miscible with water, } \\
\text { e.g., acetone, methanol, ethanol, } \\
\text { acetonitrile, THF; } \\
\text { extraction solvent: } \rho_{\text {solv. }}>\rho_{\text {aq }}, \text { e.g., } \\
\mathrm{C}_{2} \mathrm{Cl}_{4}, \mathrm{Cl} \text {-benzene, } \mathrm{CH}_{2} \mathrm{Cl}_{2}, \mathrm{CHCl}{ }_{3} \text {, } \\
\mathrm{CCl}_{4} \text {, ionic liquid; } \underline{\mathrm{OR}} \rho_{\text {solv. }}<\rho_{\mathrm{aq}}, \text { e.g., } \\
\text { 1- or 2-dodecanol, } 1 \text {-undecanol, } \\
\text { hexadecane }\left(T_{\mathrm{mp}} \approx \text { room } T\right) \text {, also } \\
\text { cyclohexane, } n \text {-hexanol, tri- } n \text {-butyl- } \\
\text { phosphate }\end{array}$ & $\begin{array}{l}\text { Disp.s.: } \\
0,1-2 \mathrm{~mL} \\
\text { Extr.s.: } \\
10-150 \\
\mu \mathrm{L}\end{array}$ & $\begin{array}{l}\text { centrifuge }\left(\rho_{\text {solv. }}>\rho_{\text {aq }}\right) ; \\
\text { ice bath or special } \\
\text { extracting vessel } \\
\left(\rho_{\text {solv. }}<\rho_{\text {aq }}\right) ; \\
\text { sample: filtration, } \\
\text { adjustment of pH and } \\
\text { ionic strength }\end{array}$ & $\begin{array}{l}\text { not needed; } \\
\text { ultrasound, } \\
\text { vortex [9] }\end{array}$ & $\begin{array}{l}\text { equilibration in } \\
\text { few seconds; } \\
\text { phase separation } \\
1-20 \text { min }\end{array}$ & non-polar & $\begin{array}{l}\text { barely } \\
\text { possible, } \\
\text { although } \\
\text { attempts [39] }\end{array}$ & $\begin{array}{l}\text { modifications: } \\
\text { temperature-controlled DLLME } \\
\text { with ionic liquids, mixing and } \\
\text { separation of phases at high/low } T \\
\text { [40] }\end{array}$ \\
\hline
\end{tabular}


All variants of LPME are equilibrium techniques, and especially SDME is not exhaustive because of the small volume of extraction solvent. Attempts towards the exhaustive SDME have been made with continuous flow microextraction (CF-ME) [34] and with multiple HS-SDME [35]. However, LPME techniques are primarily applicable to extraction of non-polar analytes from aqueous samples, and thus the equilibrium is strongly shifted to the side of organic solvent. In DLLME, the partition coefficient is sometimes less favorable due to the presence of a water-miscible disperser solvent. To overcome this drawback, dispersion of extraction solvent in the sample can be achieved by application of ultrasound-US [9], vortex-VA [9,41,42] or air [43]. Alternatively, ionic liquids with aqueous solubility depending on the temperature can be used as extraction solvents in temperature-controlled IL-DLLME [40].

In terms of time consumption, rather long equilibration times are needed in SDME because of limited stirring rate in order to keep the drop stable; thus the process in part depends on the diffusion. Extraction time is considerably shortened in dynamic-mode SDME, both in-needle and in-syringe $[44,45]$. In HF-LPME, the equilibration times are even longer than in SDME, because the analytes cross the HF wall exclusively by diffusion, although more vigorous stirring of the sample can be applied in this technique. An interesting modification allowing for high stirring rates is a HF fiber filled with solvent and sealed at both ends to become a solvent bar-solvent bar microextraction (SBE) [37]. HF-LPME can also be performed in a dynamic mode [36,45,46]. A very promising modification to shorten the extraction time is the application of electric potential across the membrane in electromembrane extraction (EME), first described by Pedersen-Bjergaard and Rasmussen [47] and useful for charged analytes $[8,10,48,49]$. In DLLME, partitioning of the analytes into the extraction solvent is almost instantaneous because of a very fine emulsion and thus increased contact surface, therefore the time is consumed mainly during the phase separation. Extraction time becomes somewhat less important in an automated process. Attempts to automation have been made both in SDME with CF-ME [34] and in DLLME [7,39], but HF-LPME is probably the technique most amenable to automation [36,46,50].

The principal considerations for the choice of solvent are outlined in Table 1. Generally, applicable solvents are non-polar and immiscible with water, especially in SDME they should also have low volatility [51]. Rather recent additions to the choice of solvents are ionic liquids $[3,13,16]$, which have been successfully applied to all here mentioned modes of LPME. As in the standard solvent extraction techniques, solvent is also selected on the basis of its similarity to the analytes, i.e., "like dissolves like", and its compatibility with the analytical technique applied to the determination of the analytes. By far the most extensively used technique in combination with LPME is gas chromatography (GC) with a variety of detectors. Most solvents applied in LPME are volatile enough to be amenable to GC. Exceptions are ionic liquids: an interesting solution to this problem is thermal desorption of analytes from the IL drop in the GC injector [52] or by a commercial thermodesorption system [53]. The next analytical technique frequently used for organic analytes is liquid chromatography (LC) on the reversed phase - RP [9]. Both RP-LC and capillary electrophoresis (CE) tolerate only water-miscible solvents. Several organic solvents used in LPME are too non-polar, therefore the common approach is to evaporate them, and then the dry extract is redissolved in a water-miscible solvent prior to RP-LC or CE. In inorganic analysis, LPME is usually followed by atomic absorption spectroscopy (AAS), inductively coupled plasma with optical emission spectroscopy or mass spectrometry (ICP-OES or 
ICP-MS) [6,7]. Applications of other analytical techniques to LPME extracts are rare, but definitely possible: UV-Vis spectrometry [20], ion-mobility spectrometry [54], X-ray fluorescence spectrometry [55] and attenuated total reflection infrared spectrometry [56].

A variety of other factors can be optimized in LPME: volume of extraction solvent, stirring rate, temperature, ionic strength and $\mathrm{pH}$ of the aqueous sample. In HF-LPME, fiber length determines the contact surface and volume of the extraction solvent. In DLLME, type and volume of both extraction (ES) and disperser (DS) solvent have to be optimized.

Many of the nuances of individual liquid-phase microextraction techniques and their optimization have been left unexplored. An interested reader can find them in more exhaustive reviews on optimization and applications of SDME [22,57], HF-LPME [10,15,48], DLLME [9,13,14,16-19] or generally on LPME $[8,12]$.

All of the LPME techniques mentioned here have been developed primarily for the extraction of analytes from aqueous samples, which belong, from the point of matrix complexity, among the samples more easily dealt with in the analytics. Aqueous samples range from the tap water with almost no interferences to the wastewater, landfill leachate and similar samples heavily loaded with interfering compounds. LPME techniques generally perform well even for these samples, although not all of them. Difficulties include clogging of hollow fiber pores or needle/syringe with particulate matter [1], dislodging of solvent drop in SDME [8,22] or adsorption of hydrophobic (macro)molecules from the sample on the surface of the hollow fiber [8]. The second problem is the interfering compounds of similar polarity as the analytes, which co-extract into solvent and complicate subsequent analysis. Due to the small volume of solvent, additional clean-up of the extract is often very difficult, although not impossible. Three-phase HF-LLLME is one of the most readily applicable solutions: unionized analyte and non-polar interferences are extracted into the hollow fiber wall, saturated with a non-polar extraction organic solvent; back-extraction of the analyte occurs into the lumen of the hollow fiber filled with acceptor solution: polar solvent [36,46,58], ionic liquid or aqueous solution of suitable $\mathrm{pH}$ to make the analyte ionized [27,28]. In SDME, two-phase solvent system has been used to extract and back-extract the analytes in an aqueous drop [31]. In DLLME, a technique of in-syringe back extraction has been developed by Melwanki and Fuh [59].

LPME can also be applied in the preparation of solid or semi-solid samples, but there are particular challenges because of the fragility of the approach (e.g., drop in DI-SDME [8]), disturbance of the equilibria processes, or both. Nevertheless, LPME has been applied to the sample preparation of (semi)solid biological and food samples [12-14,17-19,23], as well as environmental samples. The latter include soil, river or marine sediment, sewage sludge, dust, particulate matter in natural water samples and others. There are various approaches to include LPME in the preparation of this type of samples, and in this review, they have been grouped into three categories based on some common features. 
Table 2. Applications of LPME on sample extracts obtained by conventional solvent extraction.

\begin{tabular}{|c|c|c|c|c|c|c|c|c|}
\hline LPME & $\begin{array}{l}\text { Analytical } \\
\text { techn. }\end{array}$ & Sample & Analytes & $\begin{array}{l}\text { Extraction procedure } \\
\text { for solid sample }\end{array}$ & $\begin{array}{l}\text { Optimized } \\
\text { extraction } \\
\text { conditions for s.s. }\end{array}$ & LPME procedure & Method performance & Ref. \\
\hline DLLME & GC-ECD & soil & 5 PCBs & $\begin{array}{l}1 \text { g s.s. }+10 \mathrm{~mL} \mathrm{AC;} \\
\text { mech. shaking } 30 \mathrm{~min} \text {; } \\
\text { upper layer }\end{array}$ & extraction solvent & $\begin{array}{l}1.0 \mathrm{~mL} \text { AC extract (DS) }+30 \mu \mathrm{L} \mathrm{Cl}- \\
\text { benzene (ES) inj. into } 5.0 \mathrm{~mL} \text { w.; } \\
\text { centrif.; sedim. phase evaporated, } \\
\text { rediss. in } 20 \mu \mathrm{L} n \text {-hexane }\end{array}$ & $\begin{array}{l}\eta 82.3 \%-113.6 \% \text { (3 levels); } \\
\text { RSD < 6.4\%; } \\
\text { LOD 0.20-0.50 ng } / \mathrm{g}\end{array}$ & {$[60]$} \\
\hline US-DLLME & $\begin{array}{l}\text { GC-MS } \\
(\mathrm{SIM})\end{array}$ & soil & $\begin{array}{l}\text { endosulfan } \\
\& 5 \text { metab. }\end{array}$ & $\begin{array}{l}0.5 \text { g s.s. }+1.25 \mathrm{~mL} \mathrm{AC} \text {; } \\
\text { US }(10 \mathrm{~min}) \text {; centrif. }\end{array}$ & not given & $\begin{array}{l}\mathrm{AC} \text { extract }(\mathrm{DS})+58 \mu \mathrm{L} \mathrm{TCE}(\mathrm{ES}) \\
\text { inj. into } 5.0 \mathrm{~mL} \text { w. }+7 \% \mathrm{Na}_{2} \mathrm{SO}_{4} ; \mathrm{US} \\
(2 \mathrm{~min}) \text {; centrif.; direct injection }\end{array}$ & $\begin{array}{l}\text { experimental design for } \\
\text { US-DLLME optimization; } \\
\eta 89.0 \%-99.7 \% \text {; } \\
\text { RSD }<6.3 \% \text {; } \\
\text { LOD } 0.316-2.494 \mathrm{ng} / \mathrm{g} ; \\
\text { no interference from sample } \\
\text { matrix observed }\end{array}$ & {$[61]$} \\
\hline DLLME & HPLC-FLD & sediment & PAHs & $\begin{array}{l}0.2 \text { g s.s. }+2 \mathrm{~mL} \mathrm{ACN}, \mathrm{VA} \\
(2 \mathrm{~min}) \text {, centrif. }\end{array}$ & $\begin{array}{l}\text { extraction solvent, } \\
\text { vortex time }\end{array}$ & $\begin{array}{l}1.0 \mathrm{~mL} \text { ACN extract (DS) }+80 \mu \mathrm{L} \\
\mathrm{CH}_{2} \mathrm{Cl}_{2}(\mathrm{ES}) \text { inj. into } 5.0 \mathrm{~mL} \text { w.; } \\
\text { centrif.; sedim. phase evaporated, } \\
\text { rediss. in } 40 \mu \mathrm{L} \text { ACN }\end{array}$ & $\begin{array}{l}\eta 72.9 \%-97.8 \% \text { (3 levels); } \\
\text { RSD }<8.0 \% ; \text { LOD } 2.3-6.8 \\
\text { ng/g; no interference from } \\
\text { sample matrix observed }\end{array}$ & {$[62]$} \\
\hline DLLME & LC-FLD & soil & $\begin{array}{l}\text { carbaryl, } \\
\text { triazophos }\end{array}$ & $\begin{array}{l}1 \mathrm{~g} \mathrm{s.s.}+10 \mathrm{~mL} \mathrm{MeOH} \text {, } \\
\text { mech. shaking ( } 30 \mathrm{~min}) \text {; } \\
\text { filtered }\end{array}$ & extraction solvent & $\begin{array}{l}1.0 \mathrm{~mL} \mathrm{MeOH} \text { extract (DS) }+50 \mu \mathrm{L} \\
\text { TtCE (ES) inj. into } 5.0 \mathrm{~mL} \text { w.; } \\
\text { centrif.; sedim. phase evaporated, } \\
\text { rediss. in } 25 \mu \mathrm{L} \mathrm{MeOH}\end{array}$ & $\begin{array}{l}\eta 80.8 \%-111.1 \% \text { (3 levels); } \\
\text { RSD < 4.3\%; LOD 0.014- } \\
0.110 \mathrm{ng} / \mathrm{g} ; \text { some matrix } \\
\text { interferences present in } \\
\text { chromatograms }\end{array}$ & {$[63]$} \\
\hline $\begin{array}{l}\text { US-IL- } \\
\text { DLLME }\end{array}$ & HPLC-UV & soil & 3 pesticides & $\begin{array}{l}10 \text { g s.s. }+30 \mathrm{~mL} \text { sol. } \\
(60 \% \mathrm{MeOH}, 5 \mathrm{mg} \mathrm{NaCl}) \text {; } \\
\mathrm{US} \text {, centrif. + filtr.; repeat; } \\
\text { evaporated to dryness, } \\
\text { rediss. in } 10 \mathrm{~mL} \mathrm{MeOH} \\
\text { sol., pH adjust to } 4.0\end{array}$ & not given & $\begin{array}{l}1.0 \mathrm{~mL} \text { sample sol., inj. } 0.3 \mathrm{~mL} \mathrm{MeOH} \\
\text { (DS) }+70 \mu \mathrm{L} \text { [BMIM]TFSI (ES); } \\
\text { shake, US ( } 2 \mathrm{~min}) \text {; centrif.; sedim. } \\
\text { phase dissolved in } 0.5 \mathrm{~mL} \mathrm{MeOH}\end{array}$ & $\begin{array}{l}\text { not given for overall method } \\
\text { (just for DLLME) }\end{array}$ & [64] \\
\hline
\end{tabular}


Table 2. Cont.

\begin{tabular}{|c|c|c|c|c|c|c|c|c|}
\hline LPME & $\begin{array}{l}\text { Analytical } \\
\text { techn. }\end{array}$ & Sample & Analytes & $\begin{array}{l}\text { Extraction procedure } \\
\text { for solid sample }\end{array}$ & $\begin{array}{l}\text { Optimized } \\
\text { extraction } \\
\text { conditions for s.s. }\end{array}$ & LPME procedure & Method performance & Ref. \\
\hline IL-DLLME & HPLC-FLD & soil & $\begin{array}{l}5 \text { pesticides } \\
2 \text { metabol. }\end{array}$ & $\begin{array}{l}3 \text { g s.s. }+20 \mathrm{~mL} \mathrm{MeOH} \\
+2.5 \% \mathrm{NaCl} \text {; manual } \\
\text { shaking }+\mathrm{US} \text {; centrif. }+ \\
\text { filtr.; repeat; evaporated to } \\
\text { dryness, rediss. in } 10.0 \mathrm{~mL} \\
\text { w., pH adjust to } 5.2 \\
\end{array}$ & $\begin{array}{l}\text { extraction solvent, } \\
V_{\text {solv }}, \mathrm{NaCl} \text { add., } \\
\text { US time, amount } \\
\text { of sample }\end{array}$ & $\begin{array}{l}\text { add. } \mathrm{NaCl} \text { to } 30 \% \text {; } \mathrm{MeOH}(\mathrm{DS})+\mathrm{IL} \\
\left.\text { ([HMIm][} \mathrm{PF}_{6}\right], \mathrm{ES} \text { ); } \\
\text { centrif.; } 80 \mu \mathrm{L} \text { sedim. phase dissolved } \\
\text { in } 1120 \mu \mathrm{L} \text { ACN-phosphate buffer }\end{array}$ & $\begin{array}{l}\text { central composite } \\
\text { experimental design for } \\
\text { optimization of IL-DLLME } \\
\text { conditions; } \\
\eta 88 \%-119 \% \text {; } \\
\text { LOD } 0.02-27.1 \mathrm{ng} / \mathrm{g} \\
\end{array}$ & {$[65]$} \\
\hline IL-DLLME & HPLC-FLD & soil & $\begin{array}{l}7 \text { pesticides } \\
\text { and metabol. }\end{array}$ & $\begin{array}{l}3 \mathrm{~g} \text { s.s. }+20 \mathrm{~mL} \mathrm{MeOH} \\
+2.5 \% \mathrm{NaCl} \text {; manual } \\
\text { shaking + US ( } 10 \mathrm{~min}), \\
\text { centrif. + filtr.; repeat; } \\
\text { evaporated to dryness, } \\
\text { rediss. in } 10.0 \mathrm{~mL} \text { w., } \mathrm{pH} \\
\text { adjust to } 5.2\end{array}$ & not given & $\begin{array}{l}\text { comparison of } 2 \mathrm{IL} \text { as ES: } \\
{[\mathrm{PPIm}]\left[\mathrm{PF}_{6}\right] \text { and }[\mathrm{HMIm}]\left[\mathrm{PF}_{6}\right] ;} \\
\text { add. } \mathrm{NaCl}(2.5 \mathrm{~g}) ; \mathrm{MeOH}(\mathrm{DS}) 418 \mu \mathrm{L} \\
\text { + IL } 117.5 \mathrm{mg}(\mathrm{ES}) ; \mathrm{VA} 1 \mathrm{~min} ; \\
\text { centrif.; } 80 \mu \mathrm{L} \text { sedim. phase dissolved } \\
\text { in } 1120 \mu \mathrm{L} \mathrm{ACN-phosphate} \mathrm{buffer}\end{array}$ & $\begin{array}{l}\eta 93 \%-118 \% ; \mathrm{RSD}<20 \% \\
\text { LOD } 0.02-60.5 \mathrm{ng} / \mathrm{g}\end{array}$ & {$[66]$} \\
\hline DLLME & $\begin{array}{l}\text { sweeping } \\
\text { MEKC- } \\
\text { DAD }\end{array}$ & soil & $\begin{array}{l}5 \text { sulfonylurea } \\
\text { herbicides }\end{array}$ & $\begin{array}{l}10 \text { g s.s. }+10 \mathrm{~mL} \mathrm{ACN} \\
(5 \% \mathrm{HCOOH}, \mathrm{pH} 3.0) \\
\text { shaking; added } 4 \mathrm{~g} \mathrm{MgSO}_{4} \\
+1 \mathrm{~g} \mathrm{NaCl} \text {, shaking; } \\
\text { centrif.; } 5 \mathrm{~mL} \text { supernatant } \\
+250 \mathrm{mg} \mathrm{C}_{18}+1.5 \mathrm{~g} \\
\mathrm{MgSO}_{4} \text {, shaking; centrif., } \\
\text { filtered }\end{array}$ & $\begin{array}{l}\text { extraction solvent, } \\
\mathrm{pH} \text { of sample } \\
\text { solution for } \\
\text { DSPE, DSPE } \\
\text { sorbent }\end{array}$ & $\begin{array}{l}1.0 \mathrm{~mL} \text { extract }(\mathrm{DS})+50 \mu \mathrm{L} \mathrm{ClBz} \text { inj. } \\
\text { into } 5.0 \mathrm{~mL} \text { w. }(\mathrm{pH} 2.0, \mathrm{HCl}) \text {, VA }(5 \\
\text { s); centrif.; sedim. phase evaporated, } \\
\text { rediss. in } 20.0 \mu \mathrm{L} \text { phosphate buffer } \\
(\mathrm{pH} 10.0)\end{array}$ & $\begin{array}{l}\eta 76.0 \%-93.5 \% \text { (3 levels); } \\
\text { RSD <6.8\%; } \\
\text { LOD 0.5-1.0 ng/g }\end{array}$ & {$[67]$} \\
\hline
\end{tabular}


Table 2. Cont.

\begin{tabular}{|c|c|c|c|c|c|c|c|c|}
\hline LPME & $\begin{array}{l}\text { Analytical } \\
\text { techn. }\end{array}$ & Sample & Analytes & $\begin{array}{l}\text { Extraction procedure } \\
\text { for solid sample }\end{array}$ & $\begin{array}{l}\text { Optimized } \\
\text { extraction } \\
\text { conditions for s.s. }\end{array}$ & LPME procedure & Method performance & Ref. \\
\hline DLLME & $\begin{array}{l}\text { HPLC- } \\
\text { DAD }\end{array}$ & soil & $\begin{array}{l}4 \text { sulfonylurea } \\
\text { herbicides }\end{array}$ & $\begin{array}{l}10 \mathrm{~g} \text { s.s. }+20 \mathrm{~mL} \mathrm{AC} / 0.15 \\
\mathrm{M} \mathrm{NaHCO}_{3}(2: 8) \text {, shaking } \\
30 \mathrm{~min} \text {; filtered; } 10 \mathrm{~mL} \\
\text { filtrate }+0.15 \mathrm{~g} \mathrm{C}_{18}, \\
\text { shaking } 5 \mathrm{~min} \text {; filtered; } \mathrm{pH} \\
\text { adj. to } 2.0 \text { and dil. to } 25 \\
\mathrm{~mL} \text { with } \mathrm{AC} / \mathrm{w} .(2: 8, \mathrm{pH} \\
2.0)\end{array}$ & $\begin{array}{l}\text { organic solvent, } \\
\text { DSPE sorbent }\end{array}$ & $\begin{array}{l}5.0 \mathrm{~mL} \text { solution (with AC } 20 \% \text { as DS) } \\
+60 \mu \mathrm{L} \mathrm{ClBz} \text { (ES), VA } 5 \mathrm{~s} \text {; centrif.; } \\
\text { sedim. phase evaporated, rediss. in } 15 \\
\mu \mathrm{L} \mathrm{ACN}\end{array}$ & $\begin{array}{l}\eta 78.0 \%-92.5 \% \text { (3 levels); } \\
\mathrm{RSD}<7.2 \% \text {; LOD } 0.5-1.2 \\
\mathrm{ng} / \mathrm{g} ; \\
\text { some interferences present in } \\
\text { chromatograms }\end{array}$ & {$[68]$} \\
\hline DLLME & $\begin{array}{l}\text { GC- } \\
\text { MS/MS }\end{array}$ & sediment & 4 PBDEs & $\begin{array}{l}0.25 \text { g s.s. }+1.5 \mathrm{~mL} \mathrm{AC} \text {; } \\
\text { US }\left(35^{\circ} \mathrm{C}\right) 6 \times 5 \mathrm{~min} ; \\
\text { centrif.; } 1.2 \mathrm{~mL} \text { leachate }+ \\
100 \mathrm{mg} \mathrm{\textrm {SiO } _ { 2 }} \text {, VA }(30 \mathrm{~s}) \\
\text { centrif. }\end{array}$ & $\begin{array}{l}\text { leaching solvent, } \\
V_{\text {solv }}, \text { DSPE } \\
\text { sorbent, US time } \\
\& \text { mode, US- } \\
\text { transmitting liq., } \\
\text { leaching } T\end{array}$ & $\begin{array}{l}1.0 \mathrm{~mL} \text { AC extract (DS) }+60 \mu \mathrm{L} \mathrm{CCl} \\
(\mathrm{ES}) \text { inj. into } 5.0 \mathrm{~mL} \text { w.; shaking, } 5 \\
\text { min in bath }\left(35^{\circ} \mathrm{C}\right) \text {; centrif.; direct } \\
\text { injection }\end{array}$ & $\begin{array}{l}\eta 80 \%-112 \% \text { ( } 2 \text { levels); } \\
\text { RSD < } 9.8 \% \\
\text { LOD } 0.02-0.06 \mathrm{ng} / \mathrm{g} ; \\
\text { extraction method } \\
\text { comparable efficiency with } \\
\text { Soxhlet's }\end{array}$ & [69] \\
\hline DLLME & $\begin{array}{l}\text { GC- } \\
\text { MS/MS }\end{array}$ & sediment & 4 PBDEs & $\begin{array}{l}1 \text { g s.s. }+1.2 \mathrm{~mL} \mathrm{MeOH} \\
\text { US }\left(40^{\circ} \mathrm{C}\right) 2 \times 9.2 \mathrm{~min} \\
\text { centrif. }\end{array}$ & $\begin{array}{l}\text { leaching solvent } \\
\text { type (also a DS) \& } \\
V, T, \text { US time \& } \\
\text { cycles }\end{array}$ & $\begin{array}{l}0.1 \mathrm{~mL} \mathrm{MeOH}(\mathrm{DS})+22 \mathrm{mg} 1- \\
\text { dodecanol (ES) inj. into } 0.4 \mathrm{~mL} \\
\text { leachate }+1.0 \mathrm{~mL} 6.15 \mathrm{M} \mathrm{NaCl}+4.4 \\
\mathrm{~mL} \text { w. at } 40^{\circ} \mathrm{C} \text {; SFOD form. at } 10 \\
\text { min in ice bath; collected, melt, add. } 3 \\
\mu \mathrm{L} i \text {-octane; direct injection }\end{array}$ & $\begin{array}{l}\text { factorial }\left(2^{\mathrm{k}}\right) \text { screening } \& \\
\text { central composite design for } \\
\text { optimization; } \eta 71 \%-104 \% \\
\text { ( } 2 \text { levels); RSD }<9.2 \% \text {; } \\
\text { LOD } 0.5-1.8 \mathrm{pg} / \mathrm{g}\end{array}$ & {$[70]$} \\
\hline HLLE & GC-ECD & soil & $\begin{array}{l}3 \text { organo- } \\
\text { phosph. \& } \\
\text { pyrethroid } \\
\text { pesticides }\end{array}$ & $\begin{array}{l}4.0 \text { g s.s. }+10 \mathrm{~mL} \mathrm{AC;} \\
\text { mech. shaking }(30 \mathrm{~min}) \\
\text { supernatant decanted }\end{array}$ & $\begin{array}{l}\text { extraction solvent, } \\
V_{\text {solv }}\end{array}$ & $\begin{array}{l}1.0 \mathrm{~mL} \text { AC extract }(\mathrm{CS})+40 \mu \mathrm{L} \mathrm{CCl}_{4} \\
\text { (ES) inj. into } 5.0 \mathrm{~mL} \text { w.; phase } \\
\text { separation by } 0.3 \mathrm{~g} \mathrm{NaCl} \text {; centrif.; } \\
\text { direct injection }\end{array}$ & $\begin{array}{l}\eta 79.2 \%-113.1 \% \\
\text { RSD }<9.6 \% \\
\text { LOD } 0.01-0.04 \mathrm{ng} / \mathrm{g}\end{array}$ & {$[71]$} \\
\hline
\end{tabular}


Table 2. Cont.

\begin{tabular}{|c|c|c|c|c|c|c|c|c|}
\hline LPME & $\begin{array}{l}\text { Analytical } \\
\text { techn. }\end{array}$ & Sample & Analytes & $\begin{array}{l}\text { Extraction procedure } \\
\text { for solid sample }\end{array}$ & $\begin{array}{l}\text { Optimized } \\
\text { extraction } \\
\text { conditions for s.s. }\end{array}$ & LPME procedure & Method performance & Ref. \\
\hline USA-EME & GC-FID & soil & $\begin{array}{l}\text { diazinon, } \\
\text { chlorpyrifos }\end{array}$ & $\begin{array}{l}2 \text { g s.s. }+2.5 \mathrm{~mL} \mathrm{MeOH} \text {; } \\
\text { US ( } 2 \text { min pulse on/off); } \\
\text { centrif., filtered }\end{array}$ & not given & $\begin{array}{l}1.5 \mathrm{~mL} \text { extract }+10.5 \mathrm{~mL} \text { w.; } 14 \mu \mathrm{L} \\
\text { toluene slowly injected during US, US } \\
(30 \mathrm{~s}) \text {; centrif.; upper phase collection, } \\
\text { direct injection }\end{array}$ & $\begin{array}{l}\eta 90.0 \%-105 \% ; \text { RSD }< \\
9.2 \% ; \\
\text { LOD not given for soil; } \\
\text { several interferences in the } \\
\text { chromatogram }\end{array}$ & {$[72]$} \\
\hline HF-LPME & $\begin{array}{l}\text { GC-ICP- } \\
\text { MS }\end{array}$ & soil, dust & 4 PBDEs & $\begin{array}{l}0.5 \mathrm{~g} \text { soil } / 0.05 \mathrm{~g} \text { dust }+3 \\
\mathrm{~mL} \mathrm{MeOH} \text {; US ( } 30 \mathrm{~min}) ; \\
\text { centrif.; supernatant diluted } \\
\text { to } 10 \mathrm{~mL} \text { with w. }\end{array}$ & not given & $\begin{array}{l}3.0 \mathrm{~mL} \text { extract, } 4 \mu \mathrm{L} \text { decane (ES) in } \\
1.5 \text {-cm HF; stirring } 20 \text { min at } 40^{\circ} \mathrm{C} \& \\
1000 \mathrm{rpm} \text {; direct injection }\end{array}$ & $\begin{array}{l}\eta 86.7 \%-110.9 \% \\
\text { RSD }<10.4 \% \text {; } \\
\text { LOD not given for soil \& } \\
\text { dust; } \\
\text { several interferences present } \\
\text { in the chromatogram } \\
\text { (brominated compounds?) }\end{array}$ & [73] \\
\hline HF-LPME & GC-ECD & sediment & vinclozoline & $\begin{array}{l}5 \text { g s.s. + } 10 \mathrm{~mL} \text { ACN- } \\
\mathrm{MeOH}(9: 1) \text {; US } 30 \mathrm{~min} \text {; } \\
\text { centrif., evapor. to } 0.05 \mathrm{~mL}\end{array}$ & extraction solvent & $\begin{array}{l}\text { extract }+5 \mathrm{~mL} \text { w., } 3 \mu \mathrm{L} \text { toluene (ES) } \\
\text { in } 1.3 \text {-cm HF; stirring } 20 \mathrm{~min} \text { at } 800 \\
\text { rpm; direct injection }\end{array}$ & $\begin{array}{l}\eta 94 \%-96 \% \text { (2 levels); } \\
\text { RSD } 6.1 \% \\
\text { LOD } 0.5 \mathrm{ng} / \mathrm{g}\end{array}$ & [74] \\
\hline HF-LPME & HPLC-FLD & soil & $\begin{array}{l}7 \text { pesticides } \\
\text { and metabol. }\end{array}$ & $\begin{array}{l}3 \text { g s.s. }+20 \mathrm{~mL} \mathrm{MeOH} \\
+2.5 \% \mathrm{NaCl} \text {; manual } \\
\text { shaking + US (10 min); } \\
\text { centrif. + filtr.; repeat; } \\
\text { evaporated to dryness, } \\
\text { rediss. in } 10.0 \mathrm{~mL} \text { w., } \\
\text { filtered }\end{array}$ & not given & $\begin{array}{l}\text { extract (pH adj. to } 9.0, \mathrm{NaCl} \text { to } 20 \% \text { ), } \\
20 \mu \mathrm{L} 1 \text {-octanol (ES) in } 2.0-\mathrm{cm} \mathrm{HF} \text {; } \\
\text { stirring } 30 \text { min at } 1440 \mathrm{rpm} \text {; ES } \\
\text { evaporated, rediss. in } 50 \mu \mathrm{L} \text { mobile } \\
\text { phase for HPLC }\end{array}$ & $\begin{array}{l}\eta 85 \%-117 \% \text {; RSD variable, } \\
\text { up to } 71 \% \text { at low levels; } \\
\text { LOD } 0.001-6.94 \mathrm{ng} / \mathrm{g}\end{array}$ & {$[75]$} \\
\hline
\end{tabular}


Table 2. Cont.

\begin{tabular}{|c|c|c|c|c|c|c|c|c|}
\hline LPME & $\begin{array}{l}\text { Analytical } \\
\text { techn. }\end{array}$ & Sample & Analytes & $\begin{array}{l}\text { Extraction procedure } \\
\text { for solid sample }\end{array}$ & $\begin{array}{l}\text { Optimized } \\
\text { extraction } \\
\text { conditions for s.s. }\end{array}$ & LPME procedure & Method performance & Ref. \\
\hline HF-LLLME & GC-ECD & soil & chlorophenols & $\begin{array}{l}2 \text { g s.s. }+3 \mathrm{~mL} \mathrm{MeOH} \text {; US } \\
(2 \mathrm{~min} \text { pulse on/off); } \\
\text { centrif., filtered }\end{array}$ & $\begin{array}{l}\text { not given except } \\
\text { for MeOH effect } \\
\text { on HF-LLLME }\end{array}$ & $\begin{array}{l}2 \mathrm{~mL} \text { extract dil. to } 20 \mathrm{~mL} \text { with w., } \\
\text { dodecane in } 8 \text {-cm HF wall (ES) \& } 25 \\
\mu \mathrm{L} \text { ACN (AS) + IS in HF lumen; } \\
\text { stirring } 30 \mathrm{~min} \text { at } 400 \mathrm{rpm} \text {; direct } \\
\text { injection }\end{array}$ & $\begin{array}{l}\eta 86.3 \%-110 \% \\
\text { RSD }<9.3 \% \\
\text { LOD not given for soil }\end{array}$ & {$[58]$} \\
\hline $\begin{array}{l}\text { HF-LLLME, } \\
\text { dynamic }\end{array}$ & GC-FID & soil & PAHs & $\begin{array}{l}2 \text { g s.s. }+3 \mathrm{~mL} \mathrm{MeOH} \text {; US } \\
(2 \mathrm{~min} \text { pulse on/off); } \\
\text { centrif., filtered }\end{array}$ & $\begin{array}{l}\text { not given except } \\
\text { for MeOH effect } \\
\text { on HF-LLLME }\end{array}$ & $\begin{array}{l}2 \mathrm{~mL} \text { extract dil. to } 20 \mathrm{~mL} \text { with w. }+ \\
\text { dodecane in } 8 \text {-cm HF wall (ES) \& } 25 \\
\mu \mathrm{L} \text { ACN (AS) in HF lumen; stirring } \\
20 \text { min at } 1000 \mathrm{rpm} \text {; dynamic extr. } \\
\text { (syringe plunger); direct injection }\end{array}$ & $\begin{array}{l}\eta 84.4 \%-110 \% \\
\text { RSD }<9.3 \% \\
\text { LOD not given for soil }\end{array}$ & [36] \\
\hline
\end{tabular}

Abbreviations: ES — extraction solvent; DS - disperser solvent in DLLME; CS — co-solute solvent in HLLE; AS - acceptor solvent in HF-LLLME; HLLE — homogeneous LLE; DSPE - dispersive solid phase extraction; IS—internal standard; s.s. -solid sample. Solvents: AC—acetone; ACN—acetonitrile; CIBz-chlorobenzene; MeOH-methanol; TCE — trichloroethylene; TtCE—-tetrachloroethane; w. -water (ultrapure/double deionized/MilliQ); [HMIm] [PF 6 —1-hexyl-3-methylimidazolium hexafluorophosphate; [PPIm] $\left[\mathbf{P F}_{6}\right]$-1,3-dipentylimidazolium hexafluorophosphate. 


\section{Liquid-Phase Microextraction Applied to (Semi)Solid Environmental Samples as a Step for Preconcentration and Clean-up of Extracts}

\subsection{LPME Combined with Conventional Solvent Extraction}

The first category is the extraction of the analytes from the sample with a suitable organic solvent by one of the standard extraction techniques for solid samples. After that, the extraction solvent is evaporated to dryness and the dried extract is reconstituted in an aqueous solution. LPME is then performed on this solution. Alternatively, an extract in a water-miscible organic solvent is diluted with water and LPME is performed on the resulting solution. Table 2 lists the examples of this approach.

In essence, in this approach LPME is used as a means of clean-up and additional preconcentration of the extract [25], and not as a genuine extraction technique. In some methods described in Table 2, LPME was secondary to a previous clean-up of the extract by dispersive solid-phase extraction (DSPE) [67-69] and therefore served only to preconcentrate the analytes. In methods where DLLME was employed directly on the extract (previously cleaned-up or not), the organic solvent used for the extraction from the solid sample was employed also as a disperser solvent [60-63,67-70]. For this reason, the overall optimization of the method included also the choice of a suitable solvent that could efficiently serve both purposes [60,62,63,67-70]. Other parameters optimized in sample extraction were sample amount [65], solvent volume [65,69-71], influence of ionic strength and/or pH [65], extraction time $[62,65,69,70]$ and US cycles $[69,70]$, as well as temperature $[69,70]$. In some papers, no data on sample extraction optimization is given [61,64,66,72], in most cases because some previously existing method was directly applied with a novel clean-up of the obtained extract. In all the applications listed in Table 2, DLLME parameters were extensively optimized, but the details of optimization are not given here as they are essentially the same as they would be for the aqueous samples. However, additional interfering compounds could be co-extracted from the solid sample matrix and could interfere with DLLME, e.g., by hindering the phase separation after the centrifugation step [69]. In some papers, this problem was recognized and the solvent extract had to be subjected to clean-up by DSPE [67-69], which eliminated most of the interfering compounds, resulting in cleaner blank chromatograms. Nevertheless, accurate quantification could be achieved only by matrix-matched calibration [69]. Another recognized problem was the presence of co-extracted humic substances that precipitated during the DLLME step [65]. However, no problems arising from the sample matrix are reported in a majority of papers applying DLLME on solvent extracts $[60-64,66,70]$. Authors generally report low detection limits, acceptable recoveries and repeatability for the spiked samples, but no study was conducted on aged residues to establish the realistic recoveries from the environmental samples. In only one study, the results of US-DSPE-DLLME extraction were compared to results of Soxhlet-solidphase extraction (SPE) for the same samples and found to be comparable [69].

Two interesting LPME techniques that can be considered as variants of DLLME appear in the applications given in Table 2: homogeneous liquid-liquid extraction (HLLE) [71] employs a water-immiscible extraction solvent and a water-miscible co-solute solvent to obtain a homogeneous solution which is subsequently broken into two separate phases by adding a neutral salt (e.g., $\mathrm{NaCl}$ ). Solvent used for the extraction of analytes from the solid sample was also used as a co-solute solvent [71]. The other technique is ultrasound-assisted emulsification microextraction (USA-EME) [72], where 
authors achieved emulsification of the extraction solvent in the methanol-water extract solution by ultrasound. Separated solvent (upper layer) was collected using a special centrifuge vial [72].

Finally, the extracts obtained by DLLME were analyzed by the chosen optimized analytical method. In some cases, the extract had to be further diluted with a suitable solvent [64-66] or evaporated to dryness and redissolved in a solvent compatible with the analytical method $[60,62,63,67,68]$.

As can be seen from Table 2, the other group of LPME techniques employed for the clean-up and preconcentration of analytes from the solid sample extract is HF-LPME with two [73-75] or three phases [36,58]. Again, the method development emphasis in these papers has been on the optimization of HF-LPME (details not given here) and not on solvent extraction of solid samples except in one case, where different solvents were tested for their efficiency in extracting the fungicide vinclozolin from sediment samples [74]. After the extraction, the supernatant or filtrate has usually been diluted with water and subjected to HF-LPME. The residual organic solvent in the solution could adversely affect the extraction efficiency of HF-LPME, therefore some authors established the acceptable upper limit of the residual solvent $[36,58]$. In the method for PBDE extraction from soil and dust, the presence of residual solvent methanol in the solution was necessary to prevent the adsorption of analytes on the walls of a glass vial [73]. Only in one paper, the solvent extract was evaporated to dryness and redissolved in water before the HF-LPME [75]. Possible matrix interferences that could be co-extracted from the samples are high-molecular humic substances (HS) that could adsorb to the fiber. Lambropoulou and Albanis [74] performed HF-LPME in solutions with the addition of humic acids (HA) and ascertained that the extraction process was not affected by them, unlike in DI-SDME, where the extraction process was adversely affected already at HA concentrations above $10 \mathrm{mg} / \mathrm{L}$ [76], which are typical for natural waters.

No example of SDME application belonging to this category was found in the literature of the last decade, although it would certainly be feasible if the solid sample extract was evaporated to dryness and redissolved in water. However, matrix interferences such as humic substances would present a more prominent problem in this type of LPME [76] because of different solubility of the solvent in the presence of HS.

In summary, solvent consumption is decreased in this approach because of LPME, but the conventional extraction techniques for solid samples still consume a considerable volume of solvent. Typical solvent consumptions for solid samples in the methods presented in Table 2 is variable: $1.2 \mathrm{~mL}$ to $20 \mathrm{~mL}$ of pure solvent per $0.2-10 \mathrm{~g}$ sample of soil or sediment [36,58,60-75] or $0.05 \mathrm{~g}$ of house dust [73]. This may seem as a small volume, but the sample size is also small and thus, the volume of solvent per mass of sample remains approximately the same as in conventional extraction methods. However, the more established procedures for the clean-up of the extracts (e.g., SPE, DSPE) require a higher volume of sample extract, and the resulting purified extract has to be evaporated to a smaller volume to achieve preconcentration. Both steps are tedious and time-consuming. Solid-phase microextraction (SPME) is a more elegant and solventless way for the clean-up of the solid samples extracts, but the organic solvent has to be eliminated beforehand. Besides, SPME fibers are certainly more expensive than a few $\mathrm{mL}$ of organic solvent. Overall, significant advantages in the use of LPME techniques for the clean-up and preconcentration of solvent extracts from solid environmental samples are its low cost, rather short time needed for extraction and the miniaturization of the extraction process as a whole because of the small volume of solution needed for LPME, and this fact contributes to the decrease of solvent consumption and the greening of the methods. 
Table 3. Applications of LPME on solid sample extracts obtained by environmentally-friendly extraction.

\begin{tabular}{|c|c|c|c|c|c|c|c|c|}
\hline LPME & $\begin{array}{l}\text { Analytical } \\
\text { techn. }\end{array}$ & Sample & Analytes & $\begin{array}{l}\text { Extraction procedure } \\
\text { for solid sample }\end{array}$ & $\begin{array}{l}\text { Optimized extraction } \\
\text { conditions for s.s. }\end{array}$ & $\begin{array}{l}\text { LPME } \\
\text { procedure }\end{array}$ & $\begin{array}{l}\text { Method } \\
\text { performance }\end{array}$ & Ref. \\
\hline US-DLLME & GC-ECD & soil & 3 pyrethroids & $\begin{array}{l}\text { MSPD: } 0.1 \mathrm{~g} \text { s.s. }+0.3 \mathrm{~g} \mathrm{SiO}_{2}(d 38 \\
\mu \mathrm{m}) \text { blended in mortar; transf. to } \\
\text { cartridge with } 0.1 \mathrm{~g} \mathrm{Na}_{2} \mathrm{SO}_{4(\text { anhyd })} \text {; } \\
\text { eluted with } 3 \mathrm{~mL} \mathrm{AC} \text {; evaporated to } \\
0.5 \mathrm{~mL}\end{array}$ & $\begin{array}{l}\text { sorbent, sample/sorb. } \\
\text { ratio, eluting solv. } \\
\text { type and } V \text {, }\end{array}$ & $\begin{array}{l}\mathrm{AC} \text { extract (DS) }+50 \mu \mathrm{L} \text { TtCEt (ES) } \\
\text { inj. into } 5 \mathrm{~mL} \text { w.; US } 2 \text { min; centrif.; } \\
\text { sedim. phase evaporated, rediss. in } \\
20 \mu \mathrm{L} n \text {-hexane }\end{array}$ & $\begin{array}{l}\eta 83.6 \%-98.5 \% \\
\text { RSD }<7.3 \% \\
\text { LOD } 0.45-1.13 \mathrm{ng} / \mathrm{g}\end{array}$ & [77] \\
\hline DLLME & HPLC-FLD & soil & $\begin{array}{l}\text { carbendazime } \\
\text { thiabendazole }\end{array}$ & $\begin{array}{l}20 \text { g s.s. }+40 \mathrm{~mL} 0.1 \mathrm{~mol} / \mathrm{L} \mathrm{HCl} ; \\
\text { mech. shaking } 30 \mathrm{~min} \text {; filtered, } \mathrm{pH} \\
\text { adj. to } 7.0\end{array}$ & not given & $\begin{array}{l}0.75 \mathrm{~mL} \text { THF }(\mathrm{DS})+80 \mu \mathrm{L} \mathrm{CHCl}_{3} \\
\text { (ES) inj. into } 5.0 \mathrm{~mL} \text { solution }+0.5 \mathrm{~g} \\
\mathrm{NaCl} \text {; centrif.; sedim. phase } \\
\text { evaporated, rediss. in } 15 \mu \mathrm{L} \mathrm{MeOH}\end{array}$ & $\begin{array}{l}\eta 82.0 \%-93.4 \% \text { ( } 2 \text { levels }) \\
\text { RSD }<7.3 \% \\
\text { LOD } 1.0-1.6 \mathrm{ng} / \mathrm{g}\end{array}$ & [78] \\
\hline DLLME & GC-FID & sediment & PAHs & $\begin{array}{l}\text { SFE: } 1.2 \mathrm{~g} \text { s.s. }+50 \mu \mathrm{L} \mathrm{MeOH}(\mathrm{PM}) \text {; } \\
\mathrm{SFE} \text { at } T 313 \mathrm{~K}, p 253.2 \mathrm{bar} \text {, static } t_{\mathrm{extr}} \\
10 \mathrm{~min} \text {, dynamic } t_{\mathrm{extr}} 30 \mathrm{~min}, \mathrm{CO}_{2} F= \\
0.5 \mathrm{~mL} / \mathrm{min} \text {; collected in } 1 \mathrm{~mL} \mathrm{ACN} \mathrm{in} \\
\text { ice bath }\end{array}$ & $\begin{array}{l}\text { pressure, temperature, } \\
\text { static \& dynamic } \\
\text { extraction time }\end{array}$ & $\begin{array}{l}1.0 \mathrm{~mL} \text { extract }(\mathrm{DS})+16 \mu \mathrm{L} \mathrm{ClBz} \\
\text { (ES) inj. into } 5 \mathrm{~mL} \text { w.; centrif.; direct } \\
\text { injection }\end{array}$ & $\begin{array}{l}\eta 67.8 \%-98.9 \% \\
\text { RSD }<10.3 \% \\
\text { LOD } 200 \mathrm{ng} / \mathrm{g}\end{array}$ & [79] \\
\hline DLLME & GC-FID & $\begin{array}{l}\text { soil } \\
\text { sediment }\end{array}$ & $\begin{array}{l}7 \text { organo- } \\
\text { phosphor. } \\
\text { pesticides }\end{array}$ & $\begin{array}{l}\text { SFE: } 1.2 \mathrm{~g} \text { s.s. . }+50 \mu \mathrm{L} \mathrm{MeOH}(\mathrm{PM}) \\
\mathrm{SFE} \text { at } T 60^{\circ} \mathrm{C}, p 150 \mathrm{bar}, \text { static } t_{\mathrm{extr}} \\
10 \mathrm{~min}, \text { dynamic } t_{\mathrm{extr}} 30 \mathrm{~min}, \mathrm{CO}_{2} \\
F=0.5 \mathrm{~mL} / \mathrm{min} ; \text { collected in } 1 \mathrm{~mL} \\
\mathrm{ACN} \text { in ice bath }\end{array}$ & $\begin{array}{l}\text { pressure, temperature, } \\
\text { static \& dynamic } \\
\text { extraction time }\end{array}$ & $\begin{array}{l}1.0 \mathrm{~mL} \text { extract }(\mathrm{DS})+17 \mu \mathrm{LCCl}_{4} \\
\text { (ES) inj. into } 5 \mathrm{~mL} \text { w.; centrif.; direct } \\
\text { injection }\end{array}$ & $\begin{array}{l}\eta 80 \%-100 \% \\
\text { RSD }<75 \% \\
\text { LOD } 1-9 \mathrm{ng} / \mathrm{g}\end{array}$ & [80] \\
\hline DLLME & GC-FID & soil & 2 nitrotoluenes & $\begin{array}{l}\text { SFE: } 2 \text { g s.s. }+150 \mu \mathrm{L} \mathrm{MeOH} \mathrm{(PM);} \\
\text { SFE at } T 35^{\circ} \mathrm{C}, p 350 \text { atm, static } t_{\mathrm{extr}} \\
10 \mathrm{~min} \text {, dynamic } t_{\mathrm{extr}} 30 \mathrm{~min}, \mathrm{CO}_{2} F= \\
0.4 \mathrm{~mL} / \mathrm{min} \text {; collected in } 1 \mathrm{~mL} \mathrm{MeOH} \\
\text { in ice bath }\end{array}$ & $\begin{array}{l}\text { central composite } \\
\text { design to optimize } \\
\text { SFE parameters: } T \text {, } \\
\text { pressure, } V_{\mathrm{PM}}, \\
\text { dynamic } t_{\mathrm{extr}} \\
\end{array}$ & $\begin{array}{l}1.0 \mathrm{~mL} \text { extract }(\mathrm{DS})+20 \mu \mathrm{LCCl}_{4} \\
\text { (ES) inj. into } 5.0 \mathrm{~mL} \text { w. }(3 \% \mathrm{NaCl}) \text {; } \\
\text { centrif.; direct injection }\end{array}$ & $\begin{array}{l}\eta 80 \%-84 \% \\
\text { RSD }<6.5 \% \\
\text { LOD } 0.12 \mu \mathrm{g} / \mathrm{g}\end{array}$ & [81] \\
\hline DLLME & GC-MS & sediment & $\begin{array}{l}\text { hydroxylated } \\
\text { PAHs }\end{array}$ & $\begin{array}{l}\text { SWE: } 10 \mathrm{~g} \text { s.s. }+2 \mathrm{~g} \text { diatomaceous } \\
\text { earth; PLE with w. pH } 3.0+20 \% \\
\text { ACN (OM) } 10 \text { min at } 150^{\circ} \mathrm{C} \& 1500 \\
\text { psi; purged with } \mathrm{N}_{2} \text {, collected } 11 \mathrm{~mL} \\
\text { extract }\end{array}$ & $\begin{array}{l}\text { type and } V \text { of organic } \\
\text { modifier for SWE, } \\
\text { pH, } T \text {, pressure, extr. } \\
\text { time }\end{array}$ & $\begin{array}{l}100 \mu \mathrm{L} \mathrm{ClBz} \text { (ES) inj. into } 11 \mathrm{~mL} \\
\text { extract ( } 20 \% \text { ACN as DS); VA } 30 \mathrm{~s} \text {; } \\
\text { centrif.; sedim. phase evaporated, } \\
\text { added } 50 \mu \mathrm{L} \text { MTBSTFA to derivatize, } \\
\text { evaporated, rediss. in } 100 \mu \mathrm{L} \text { AC }\end{array}$ & $\begin{array}{l}\eta 57.63 \%-91.07 \% \\
\text { RSD }<11.07 \% \text {; } \\
\text { LOD } 0.0139-0.2334 \mathrm{ng} / \mathrm{g} \text {; } \\
\text { comparison with SWE-SPE - all } \\
\text { parameters better for SWE-DLLME }\end{array}$ & [82] \\
\hline
\end{tabular}


Table 3. Cont.

\begin{tabular}{|c|c|c|c|c|c|c|c|c|}
\hline LPME & $\begin{array}{l}\text { Analytical } \\
\text { techn. }\end{array}$ & Sample & Analytes & $\begin{array}{l}\text { Extraction procedure } \\
\text { for solid sample }\end{array}$ & $\begin{array}{l}\text { Optimized extraction } \\
\text { conditions for s.s. }\end{array}$ & $\begin{array}{l}\text { LPME } \\
\text { procedure }\end{array}$ & $\begin{array}{l}\text { Method } \\
\text { performance }\end{array}$ & Ref. \\
\hline DLLME & GC-MS & $\begin{array}{l}\text { pyrolysis } \\
\text { solid residue }\end{array}$ & $\begin{array}{l}15 \text { aromatic } \\
\text { volatiles }\end{array}$ & $\begin{array}{l}\text { extracted s.s. (extr. with } \mathrm{CH}_{2} \mathrm{Cl}_{2} \text { ) and } \\
\text { raw s.s. leached with } 0.001 \mathrm{M} \mathrm{CaCl}_{2} \\
\text { sol. (leach test } \\
\text { ISO/TS 21268-2) }\end{array}$ & not given & $\begin{array}{l}0.5 \mathrm{~mL} \mathrm{AC} \mathrm{(DS)}+50 \mu \mathrm{L} \mathrm{CCl}_{4}(\mathrm{ES}) \\
\text { inj. into } 5.0 \mathrm{~mL} \text { leachate; centrif.; } \\
\text { direct injection }\end{array}$ & $\begin{array}{l}\text { LOD } 1.02-24.6 \mathrm{ng} / \mathrm{L}^{\mathrm{a}} \text {; } \\
\text { compared with static HS and HS- } \\
\text { SPME (both lower LODs) }\end{array}$ & [83] \\
\hline DLLME & GC-MS & $\begin{array}{l}\text { pyrolysis } \\
\text { solid residue }\end{array}$ & 11 alkylphenols & $\begin{array}{l}\text { extracted s.s. (extr. with } \mathrm{CH}_{2} \mathrm{Cl}_{2} \text { ) and } \\
\text { raw s.s. leached with } 0.001 \mathrm{M} \mathrm{CaCl}_{2} \\
\text { sol. (leach test } \\
\text { ISO/TS 21268-2) }\end{array}$ & not given & $\begin{array}{l}1.0 \mathrm{~mL} \text { AC (DS) }+15 \mu \mathrm{L} \text { TtCEt (ES) } \\
\text { inj. into } 4.0 \mathrm{~mL} \text { leachate }+\mathrm{NaCl} \\
(15 \%) \text {; centrif.; direct injection }\end{array}$ & $\begin{array}{l}\eta \quad 61.9 \%-101.4 \% \\
\text { RSD }<8.0 \% \\
\text { LOD } 0.07-0.17 \mu \mathrm{g} / \mathrm{L}^{\mathrm{b}}\end{array}$ & {$[84]$} \\
\hline DLLME & GC-MS & $\begin{array}{l}\text { particul. } \\
\text { matter in } \\
\text { seawater }\end{array}$ & 8 UV filters & $\begin{array}{l}\text { unfiltered seawater, US } 15 \text { min; } \mathrm{pH} \\
\text { adj. to } 2.5 \text { with acetic a.; filtered }\end{array}$ & US time & $\begin{array}{l}250 \mu \mathrm{L} \mathrm{AC} \mathrm{(DS)}+50 \mu \mathrm{L} \mathrm{CHCl}_{3} \\
\text { (ES) inj. into } 5.0 \mathrm{~mL} \text { sample; centrif.; } \\
\text { direct injection }\end{array}$ & $\begin{array}{l}\eta 88 \%-117 \% \text { ( } 2 \text { levels }) \\
\text { RSD }<14 \% \\
\text { LOD } 10-30 \mathrm{ng} / \mathrm{L}^{\text {a }}\end{array}$ & {$[85]$} \\
\hline $\begin{array}{l}\text { DLLME \& } \\
\text { in-syringe } \\
\text { back-extract. }\end{array}$ & HPLC-UV & $\begin{array}{l}\text { soil } \\
\text { sediment }\end{array}$ & 5 chlorophenols & $\begin{array}{l}\text { MWE: } 1.2 \text { g s.s. }+2 \mathrm{~mL} \text { w. (pH } 10.0 \text { ); } \\
\text { MWE } 90 \mathrm{~s} \text {, cooling, diluted to } 5 \mathrm{~mL} \\
\text { with w., pH adj. to } 6.0 \text {; centrif., } \\
\text { filtered }\end{array}$ & $\begin{array}{l}V_{\text {solv }}, \mathrm{pH}_{\text {solv }}, \mathrm{MWE} \\
\text { time }\end{array}$ & $\begin{array}{l}1.0 \mathrm{~mL} \text { AC (DS) }+37 \mu \mathrm{L} \mathrm{ClBz}(\mathrm{ES}) \\
\text { inj. into } 5.0 \mathrm{~mL} \text { extract; centrif.; } 20 \mu \mathrm{L} \\
\text { sedim. phase in syringe, then } 20 \mu \mathrm{L} \\
\text { w. (pH 12.0), plunger moving } 5 \mathrm{~min} \text {; } \\
\text { w. phase injected }\end{array}$ & $\begin{array}{l}\eta 66.1 \%-82.0 \% \\
\text { RSD }<7.6 \% \\
\text { LOD } 0.5-2.0 \mathrm{ng} / \mathrm{g} ; \text { chromatograms } \\
\text { free of interferences }\end{array}$ & [86] \\
\hline USA-EME & HPLC-DAD & soil & triazine herbicides & $\begin{array}{l}10 \text { g s.s. }+10 \mathrm{~mL} \text { w.; mech. shaking } \\
40 \mathrm{~min} \text {; filtered, diluted to } 10.0 \mathrm{~mL} \\
\text { with w. }\end{array}$ & not given & $\begin{array}{l}5.0 \mathrm{~mL} \text { extract }+100 \mu \mathrm{L} \mathrm{ClBz} \text {; } \mathrm{US} 3 \\
\text { min at } 25^{\circ} \mathrm{C} \text {; centrif.; sedim. phase } \\
\text { evaporated, rediss. in } 20 \mu \mathrm{L} \mathrm{MeOH}\end{array}$ & $\begin{array}{l}\eta 82.6 \%-92 \% \text { ( } 2 \text { levels); } \\
\text { RSD }<4.3 \% ; \\
\text { LOD } 0.1-0.5 \mathrm{ng} / \mathrm{g}\end{array}$ & [87] \\
\hline ATPS & HPLC-UV & soil & 2 phytohormones & $\begin{array}{l}10 \text { g s.s. }+30 \mathrm{~mL} \mathrm{MeOH} / \mathrm{w} .(80: 20) \\
\text { US } 20 \mathrm{~min} \text {; centrif.; repeat; filtered, } \\
\text { evaporated, rediss. in } 10 \mathrm{~mL} \mathrm{MeOH/w.} \\
(80: 20, \mathrm{pH} 3)\end{array}$ & not given & $\begin{array}{l}1.0 \mathrm{~mL} \text { solution }+0.6 \mathrm{~g}[\mathrm{BMIM}] \mathrm{Br}+ \\
0.75 \mathrm{~g} \mathrm{~K}_{2} \mathrm{HPO}_{4} ; \text { stirred } 10 \mathrm{~min} \text { at } 30^{\circ} \mathrm{C} \text {; } \\
\text { centrif.; upper phase collected, direct } \\
\text { injection }\end{array}$ & $\begin{array}{l}\eta 86 \%-102 \% ; \text { RSD }<5.3 \% ; \\
\text { LOD } 2-10 \mathrm{ng} / \mathrm{g} ; \text { compared to direct } \\
\text { HF-LPME }\end{array}$ & {$[88]$} \\
\hline CAE-ME & HPLC-DAD & sediment & $\begin{array}{l}\text { PAHs, alkyl- } \\
\text { phenols, paraben }\end{array}$ & $\begin{array}{l}\text { MWE: } 0.1 \mathrm{~g} \text { s.s. }+3 \mathrm{~mL} 40 \mathrm{mM} \text { CTAB } \\
\text { solution; MWE for } 6 \mathrm{~min} \text { at } 90^{\circ} \mathrm{C} \text { and } \\
140 \mathrm{~W} \text {, cooled; centrif., filtered }\end{array}$ & $\begin{array}{l}T, \text { MW power, CTAB } \\
\text { solution } V \text { and } \\
\text { concentration }\end{array}$ & $\begin{array}{l}2 \mathrm{~mL} \text { solution }+200 \mu \mathrm{L} \text { ACN }+46 \\
\mu \mathrm{L} \mathrm{Li}-\mathrm{NTf}_{2} 0.5 \mathrm{~g} / \mathrm{mL} ; \mathrm{VA} 3 \mathrm{~min} ; \\
\text { heated } 2 \mathrm{~min} \text { at } 65^{\circ} \mathrm{C} \text {; centrif; } \\
\text { sedimented droplet dil. to } 100 \mu \mathrm{L} \\
\text { with ACN, VA }\end{array}$ & $\begin{array}{l}\eta 92.8 \%-95.7 \% \text { ( } 2 \text { levels); } \\
\text { RSD }<19.3 \% ; \\
\text { LOQ } 0.02-0.36 \mu \mathrm{g} / \mathrm{g} ; \\
\text { several interferences from the } \\
\text { sample co-extracted }\end{array}$ & [89] \\
\hline
\end{tabular}


Table 3. Cont.

\begin{tabular}{|c|c|c|c|c|c|c|c|c|}
\hline LPME & $\begin{array}{l}\text { Analytical } \\
\text { techn. }\end{array}$ & Sample & Analytes & $\begin{array}{l}\text { Extraction procedure } \\
\text { for solid sample }\end{array}$ & $\begin{array}{l}\text { Optimized extraction } \\
\text { conditions for s.s. }\end{array}$ & $\begin{array}{l}\text { LPME } \\
\text { procedure }\end{array}$ & $\begin{array}{l}\text { Method } \\
\text { performance }\end{array}$ & Ref. \\
\hline $\begin{array}{l}\text { in-situ LPME } \\
\text { with IL-based } \\
\text { surfactant }\end{array}$ & HPLC-DAD & sediment & $\begin{array}{l}\text { PAHs, alkyl- } \\
\text { phenols, paraben }\end{array}$ & $\begin{array}{l}\text { MWE: } 0.1 \text { g s.s. }+3-5 \mathrm{~mL} 40 \mathrm{mM} \\
\mathrm{C}_{16} \mathrm{MIm}-\mathrm{Br} \text { sol.; } \mathrm{MWE} \text { for } 6 \text { min at } 90^{\circ} \mathrm{C} \\
\text { and } 140 \mathrm{~W} \text {, cooled; centrif., filtered }\end{array}$ & $\begin{array}{l}T, \text { type of ILS, ILS } \\
\text { solution } V \text { and } \\
\text { concentration }\end{array}$ & $\begin{array}{l}4 \mathrm{~mL} \text { solution }+800 \mu \mathrm{L} \text { ACN }+92 \\
\mu \mathrm{L} \text { Li-NTf } 20.5 \mathrm{~g} / \mathrm{mL} \text {; heated } 5 \mathrm{~min} \\
\text { at } 65{ }^{\circ} \mathrm{C} \text {; VA } 3 \mathrm{~min} \text {; centrif.; } \\
\text { sedimented droplet }(\approx 90 \mu \mathrm{L}) \text { dil. to } \\
200 \mu \mathrm{L} \text { with } \mathrm{ACN}, \mathrm{VA}\end{array}$ & $\begin{array}{l}\eta(2 \text { levels }) 91.1 \%-127 \% \\
\text { RSD }<19 \% \\
\text { LOQ } 0.04-1.0 \mu \mathrm{g} / \mathrm{g}\end{array}$ & [90] \\
\hline $\begin{array}{l}\text { HF-LPME; } \\
\text { DLLME }\end{array}$ & GC-FPD & soil & $\begin{array}{l}6 \text { organosulfur } \\
\text { pesticides }\end{array}$ & $\begin{array}{l}5 \mathrm{~g} \text { s.s. }+10 \mathrm{~mL} \text { w.; US } 40 \mathrm{~min} \text {; } \\
\text { centrif.; used for HF-LPME or filtered } \\
(2 \times) \text {, diluted } 25 \times \text { with w. for DLLME }\end{array}$ & not given & $\begin{array}{l}\text { HF-LPME: } 5.0 \mathrm{~mL} \text { extract, } 5 \mu \mathrm{L} o- \\
\text { xylene (ES) in 1-cm HF; stirring } 35 \\
\text { min at } 1200 \mathrm{rpm} \text {; direct injection } \\
\text { DLLME: } 0.8 \mathrm{~mL} \mathrm{MeOH} \mathrm{(DS)} \mathrm{+} 10 \\
\mu \mathrm{L} \mathrm{CCl}{ }_{4}(\mathrm{ES}) \text { inj. into } 5.0 \mathrm{~mL} \\
\text { solution; centrif.; direct injection }\end{array}$ & $\begin{array}{l}\text { HF-LPME: } \eta \text { 81.7\%-109.2\%; RSD } \\
<9.6 \% \text {; DLLME: } \eta 87.8 \%-100.6 \% \text {; } \\
\text { RSD < } 9.0 \% \text {; LOD not given for } \\
\text { soil samples } \\
\text { Comparison: DLLME faster \& } \\
\text { higher capacity, HF-LPME more } \\
\text { robust \& simple for complex } \\
\text { samples }\end{array}$ & [91] \\
\hline HF-LPME & GC-MS & sediment & $\begin{array}{l}12 \text { OCPs } \\
8 \text { PCBs }\end{array}$ & $\begin{array}{l}\text { MWE: } 1 \mathrm{~g} \text { s.s. }+10 \mathrm{~mL} \text { w.; MWE at } \\
600 \mathrm{~W} \text { for } 20 \mathrm{~min} \text { at } 80^{\circ} \mathrm{C} \text {; } \\
\text { supernatant diluted to } 10 \mathrm{~mL}\end{array}$ & $T$, extraction time & $\begin{array}{l}10 \mathrm{~mL} \text { extract, } 5 \mu \mathrm{L} \text { toluene (ES) in } \\
1.3-\mathrm{cm} \text { HF; stirring } 20 \mathrm{~min} \text { at } \\
700 \mathrm{rpm} \text {; direct injection }\end{array}$ & $\begin{array}{l}\eta 73 \%-111 \% \text { (OCP) } 86-110 \% \\
(\mathrm{PCB}) ; \mathrm{RSD}<20 \% \text {; LOD } 0.07- \\
0.70 \mathrm{ng} / \mathrm{g}\end{array}$ & [92] \\
\hline HF-LLLME & LC-ESI-MS & $\begin{array}{l}\text { dried sewage } \\
\text { sludge }\end{array}$ & NSAIDs & $\begin{array}{l}\text { PHWE: } 0.5 \mathrm{~g} \mathrm{s.s.}+20 \mathrm{~g} \text { sea sand, PLE } \\
\text { with } 0.01 \mathrm{M} \mathrm{NaOH} 5 \mathrm{~min}(5 \mathrm{cyc} \text {.) at } \\
120^{\circ} \mathrm{C} \& 100 \text { bar, flush } V 60 \% \text {; } \\
\text { purged with } \mathrm{N}_{2} \text {, collected } 90 \mathrm{~mL} \\
\text { extract adj. pH to } 1.5 \text { and diluted to } \\
100 \mathrm{~mL}\end{array}$ & $\begin{array}{l}\mathrm{pH} \text { of solvent, } T \text {, } \\
\text { number of cycles, } \\
\text { flush volume }\end{array}$ & $\begin{array}{l}100 \mathrm{~mL} \text { extract, DHE in } 10-\mathrm{cm} \mathrm{HF} \\
\text { wall (ES) \& } 25 \mu \mathrm{L} 0.1 \mathrm{M}\left(\mathrm{NH}_{4}\right)_{2} \mathrm{CO}_{3} \\
\text { (AS) in } \mathrm{HF} \text { lumen; stirring } 120 \mathrm{~min} \\
\text { at } 600 \mathrm{rpm} \text {; direct injection }\end{array}$ & $\begin{array}{l}\eta \text { (PHWE) 101\%-109\% (spike), } \\
38.9 \%-90.3 \% \text { (native); } \eta \text { (HF- } \\
\text { LPME) } 23.6 \%-30.3 \% \text {; RSD }<20 \% \text {; } \\
\text { LOD } 0.4-3.7 \mathrm{ng} / \mathrm{g} \text {; only small } \\
\text { matrix effect in ESI }\end{array}$ & [93] \\
\hline HF-LLLME & LC-ESI-MS & $\begin{array}{l}\text { dried sewage } \\
\text { sludge }\end{array}$ & SSRIs & $\begin{array}{l}\text { PHWE: } 0.5 \text { g s.s. }+20 \mathrm{~g} \text { sea sand; PLE } \\
\text { with } 0.05 \mathrm{M} \mathrm{H}_{3} \mathrm{PO}_{4} \mathrm{pH} 2 \text { for } 5 \mathrm{~min}(5 \\
\text { cyc.) at } 120^{\circ} \mathrm{C} \& 100 \text { bar, flush } V \\
90 \% \text {; purged with } \mathrm{N}_{2} \text {, collected } 90 \mathrm{~mL} \\
\text { extract adj. pH to } 12.4 \text { and diluted to } \\
100 \mathrm{~mL}\end{array}$ & $\begin{array}{l}\mathrm{pH} \text { of solvent, } T \text {, } \\
\text { number of cycles, } \\
\text { flush volume }\end{array}$ & $\begin{array}{l}100 \mathrm{~mL} \text { extract, DHE in 10-cm HF } \\
\text { wall (ES) \& } 0.1 \mathrm{M}\left(\mathrm{NH}_{4}\right) \mathrm{H}_{2} \mathrm{PO}_{4} \mathrm{pH} \\
2.1 \text { (AS) in } \mathrm{HF} \text { lumen; stirring } 8 \mathrm{~h} \text {; } \\
\text { direct injection }\end{array}$ & $\begin{array}{l}\eta \text { (PHWE) 67\%-83\%(spike) } \\
72.2 \%-85.8 \% \text { (native); } \eta \text { (HF- } \\
\text { LPME) } 29 \%-47 \% \text {; RSD }<20.8 \% \text {; } \\
\text { LOD } 6 \mathrm{ng} / \mathrm{g} \text {; comparison to direct } \\
\text { HF-LLLME method (without } \\
\text { PHWE) }\end{array}$ & [94] \\
\hline
\end{tabular}


Table 3. Cont.

\begin{tabular}{|c|c|c|c|c|c|c|c|c|}
\hline LPME & $\begin{array}{l}\text { Analytical } \\
\text { techn. }\end{array}$ & Sample & Analytes & $\begin{array}{l}\text { Extraction procedure } \\
\text { for solid sample }\end{array}$ & $\begin{array}{l}\text { Optimized extraction } \\
\text { conditions for s.s. }\end{array}$ & $\begin{array}{l}\text { LPME } \\
\text { procedure }\end{array}$ & $\begin{array}{l}\text { Method } \\
\text { performance }\end{array}$ & Ref. \\
\hline HF-LLLME & LC-MS/MS & $\begin{array}{l}\text { sewage } \\
\text { sludge }\end{array}$ & $\begin{array}{l}\text { SSRIs and } \\
\text { metabolites }\end{array}$ & $\begin{array}{l}1 \text { g s.s. }+1.1 \mathrm{~L} \mathrm{w} .+20 \mu \mathrm{L} \mathrm{HCOOH} \\
\text { stirred } 16 \mathrm{~h} \text { at } 900 \mathrm{rpm} \text {; filtered, } \\
\text { diluted } 1: 100 \text { or } 1: 20\end{array}$ & not given & $\begin{array}{l}\text { solution + IS + } 10 \mathrm{~mL} 5 \mathrm{M} \mathrm{NaOH} \text {, } \\
\text { DHE in } 28-\mathrm{cm} \mathrm{HF} \text { wall (ES) \& } 20 \mu \mathrm{L} \\
\text { w. }+\mathrm{HCOOH} \mathrm{pH} 2 \text { (AS) in HF lumen; } \\
\text { stirring } 2 \text { h at } 800 \mathrm{rpm} \text {; direct } \\
\text { injection }\end{array}$ & $\begin{array}{l}\eta 26.2 \%-71.4 \% \\
\text { RSD }<24.6 \%(\text { SSRI) } \\
<51 \% \text { (metab.); } \\
\text { LOD not given }\end{array}$ & [95] \\
\hline DI-SDME & $\begin{array}{l}\text { AP-MALDI- } \\
\text { MS }\end{array}$ & soil & $\begin{array}{l}\text { antibiotic } \\
\text { monensin }\end{array}$ & $\begin{array}{l}5 \text { g s.s. }+15 \mathrm{~mL} \text { w. }(10 \% \mathrm{NaCl}) \text {; } \\
\text { shaking } 5 \mathrm{~min} \text {, US } 5 \mathrm{~min} \text {; centrif., } \\
\text { repeat; supernatants collected }\end{array}$ & not given & $\begin{array}{l}20.0 \mathrm{~mL} \text { solution }+10 \% \mathrm{NaCl}, 1.5 \mu \mathrm{L} \\
\mathrm{CHCl}_{3} / \text { toluene }(1: 1) \text { drop immersed } \\
\text { for } 10 \mathrm{~min} \text { at } 240 \mathrm{rpm} \text {; direct } \\
\text { injection }\end{array}$ & $\begin{array}{l}\eta 74.5 \%-82.8 \% \text { (3 levels); } \\
\text { RSD }<6.5 \% \\
\text { LOD } 12.4 \mathrm{ng} / \mathrm{mL}^{\mathrm{b}}\end{array}$ & [96] \\
\hline HS-SDME & GC-FID & fire debris & fire accelerants & $\begin{array}{l}20 \times 20 \mathrm{~cm} \text { piece of textile soaked with } \\
\text { accelerant, ignited; debris }+100 \mathrm{~mL} \\
\text { w., mixed } 3 \mathrm{~min} \text {; centrif., filtered }\end{array}$ & sample volume & $\begin{array}{l}10 \mathrm{~mL} \text { filtrate stirred at } 1500 \mathrm{rpm}, \\
2.5 \mu \mathrm{L} \text { benzyl alcohol drop exposed } \\
\text { to } \mathrm{HS} \text { for } 20 \mathrm{~min} \text {; direct injection }\end{array}$ & LOD $0.15 \mathrm{mg} / \mathrm{L}^{\mathrm{a}}$ & [97] \\
\hline ESy & $\begin{array}{l}\text { GC-ECD } \\
\text { GC-MS }\end{array}$ & soil & OCPs & $\begin{array}{l}1 \mathrm{~g} \text { s.s. }+10 \mathrm{~mL} \text { w. } / \mathrm{ACN}(8: 2) ; \\
\text { US } 15 \text { min; centrif.; supernatant }+70 \mu \mathrm{L} \\
\text { conc. } \mathrm{H}_{3} \mathrm{PO}_{4}+100 \mathrm{mg} \mathrm{Cu} \text { granules; } \\
\text { US } 15 \text { min; filtered }\end{array}$ & $\begin{array}{l}\text { ACN addition to extr. } \\
\text { solvent }\end{array}$ & $\begin{array}{l}3 \mathrm{~mL} \text { filtrate flushed through donor } \\
\text { side ESy at } 100 \mu \mathrm{L} / \mathrm{min} \text {; acceptor } \\
\text { phase: } n \text {-undecane; direct injection }\end{array}$ & $\begin{array}{l}\text { compared with SE and PLE: } \\
\text { comparable results, less solvent ( 4 } \\
\mathrm{mL} v s .420 \mathrm{~mL}-\mathrm{SE} \text { or } 18 \mathrm{~mL}-\mathrm{PLE}) \\
\text { and time ( } 1.5 \mathrm{~h} v s .4 \mathrm{~h}-\mathrm{SE} \text { or } 0.85 \mathrm{~h} \text { - } \\
\text { PLE), less s.s. }\end{array}$ & [98] \\
\hline
\end{tabular}

${ }^{\mathrm{a}}$ given in liquid sample/leachate/filtrate; ${ }^{\mathrm{b}} \mathrm{LOD}$ for soil given in ng/mL. Abbreviations: ES — extraction solvent; DS — disperser solvent in DLLME; AS — acceptor solvent in HF-LLLME; PM—polar modifier in SFE; OM—organic modifier in PLE; ATPS — aqueous two-phase system; ESy — extracting syringe; MSPD — matrix solid phase dispersion; s.s.—solid sample. Solvents: AC—acetone; ACN—acetonitrile; CIBz-chlorobenzene; DHE-di- $n$-hexyl ether; ILS—ionic liquid-based surfactant, MeOH — methanol; THF — tetrahydrofuran; TtCEt — tetrachloroethylene; w. — water (ultrapure/double deionized/MilliQ). Reagents: CTAB — cetyltrimethylammonium bromide; Li-NTf $_{2}$ - lithium bis[(trifluoromethane)sulfonyl]imide; MTBSTFA- $N$-(tert-butyldimethylsilyl)- $N$-methyl-trifluoroacetamide; [BMIm]Br-1-butyl-3-methylimidazolium bromide; $\mathbf{C}_{\mathbf{1 6}} \mathbf{M I m}-\mathbf{B r}$-1-hexadecyl-3-methylimidazolium bromide. 


\subsection{LPME Combined with Environmentally-Friendly Extraction}

The second category of LPME applications for solid environmental samples also employs an extraction technique before LPME, but in this case, more environmentally friendly solvents are used: supercritical $\mathrm{CO}_{2}$ in SFE; water in SWE or PHWE; aqueous solutions, ionic liquids or surfactants as extraction solvents in combination with ultrasound or microwaves. LPME technique is necessary as a step to preconcentrate the analytes from the aqueous extract. Examples are given in Table 3.

As in the first category, LPME techniques are used as a means to clean-up and preconcentrate the extracts of solid samples, but these extracts are now prepared with environmentally friendly extraction methods. One frequent feature of the published methods, compared to the previous category, is the more extensive optimization of extraction parameters.

Supercritical fluid extraction (SFE) was used to extract pollutants of various polarities (PAHs, organophosphorus pesticides, nitrotoluenes) from sediment and soil samples [79-81]. With this extraction method, a small volume of polar modifier, i.e., organic solvent, is added to supercritical $\mathrm{CO}_{2}$. In all three published methods, $50-150 \mu \mathrm{L}$ of methanol per extract was used for this purpose [79-81]. However, the final SFE extract was collected in $1 \mathrm{~mL}$ of acetonitrile [79,80] or methanol [81]. The LPME technique following SFE was DLLME, therefore the collecting solvent essentially served as a disperser solvent in DLLME as well [79-81]. The overall consumption of organic solvent per sample was thus no higher than in the case of DLLME of an aqueous sample. In all methods, SFE was optimized in terms of pressure, temperature, static and dynamic extraction time [79-81], and also volume of polar modifier [81]. Since SFE can be optimized to provide the best selectivity for analyte extraction from the sample matrix, there are no reports of any interfering compound being co-extracted. Performance of the extraction method was satisfactory in all papers. Rezaee et al. [79] compared their SFE-DLLME procedure to Soxhlet extraction. Recoveries were comparable, but the consumption of solvents and time was greatly diminished in SFE-DLLME.

Most methods listed in Table 3, however, employ water or a mixture of water and a water-miscible organic solvent to extract the pollutants. Supercritical water extraction (SWE)/pressurized hot water extraction (PHWE) was performed as PLE in a commercial $\mathrm{ASE}^{\circledR}$ apparatus [82,93,94]. Also in this method, a certain amount (up to $20 \%$ ) of organic modifier - acetonitrile - could be of benefit to the extraction efficiency [82], but was not absolutely necessary for other analytes [93,94]. Organic modifier also served as a disperser solvent in the subsequent DLLME [82]. One of the main parameters affecting the extraction yield is the $\mathrm{pH}$ of the extraction solution, which was optimized in all cases $[82,93,94]$, besides the temperature $[82,93,94]$, pressure, extraction time, type and volume of organic modifier [82] or number of extraction cycles and the final flush volume [93,94]. Pressure of the supercritical water could be the decisive factor in the co-extraction of interfering compounds, yet it was not optimized in all methods. Higher pressure means more dissolved organic matter, which interferes with DLLME process, resulting in its lower efficiency [82]. In two methods published by the same research group [93,94], the subsequent LPME technique was HF-LLLME. In the acceptor solvent in the fiber lumen, as well as in PHW before that, $\mathrm{pH}$ was adjusted to a similar value to promote the transfer of analytes into the solvent: alkaline $\mathrm{pH}$ in the extraction of non-steroidal anti-inflammatory drugs (NSAIDs) from sewage sludge [93] or acidic $\mathrm{pH}$ cca. 2 in the case of extraction of selective serotonin reuptake inhibitors (SSRIs) from the sewage sludge [94]. 
Another extraction technique employed is microwave-assisted extraction (MWE) [86,89,90,92]. Water with suitably adjusted $\mathrm{pH}$ was used as an extraction solvent [86,92] and its volume and $\mathrm{pH}[86]$, as well as extraction time [86,92] and temperature [92] were optimized. HF-LPME was subsequently applied [92] or DLLME with innovative in-syringe back-extraction from a thin layer of DLLME sedimented phase into water with alkaline $\mathrm{pH}[86]$.

In all other methods described in Table 3 where an aqueous solution was used as an extraction solvent, ultrasound $[85,91,96,98]$ or mechanical shaking/stirring $[78,83,84,87,95,97]$ were applied to facilitate the extraction of analytes. In many methods, no data on the extraction optimization are given $[78,83,84,87,91,95,96]$. In others, the following parameters were optimized: ultrasound time [85], sample volume [97] or the addition of organic solvent to water [98]. On the sample extract, DLLME was applied [78,83-85,91], also HF-LPME [91], HF-LLLME [95], DI-SDME [96] or HS-SDME [97]. Xiong and $\mathrm{Hu}$ [91] compared HF-LPME and DLLME for the same US aqueous extract of organosulfur pesticides from the soil. Methods were comparable in terms of recovery and precision, but DLLME was found to be faster and had a higher capacity, while HF-LPME was more robust and simpler to employ on complex samples [91]. Wu et al. [87] applied USA-EME on the aqueous extract of triazines from the soil. An innovative approach named Extracting Syringe (ESy) was developed by Barri et al. [98]: an aqueous donor solution of analytes was flushed through a microchannel and analytes were extracted through a membrane into non-polar solvent present in the opposite microchannel. The process was automated, method performance was comparable with solvent extraction or PLE, but with decreased solvent and sample consumption and decreased or comparable extraction time [98].

Dong et al. [88] proposed an aqueous two-phase system (ATPS) following US-assisted extraction of phytohormones from the soil by a mixture of methanol and water. In ATPS, ionic liquid was added to the methanol-water solution and the phases were separated following the addition of an inorganic salt. Method had an excellent performance and was compared with direct HF-LPME with a similar IL in a solvent bar for extraction from the soil suspension in $\mathrm{NaCl}$ solution, which gave slightly poorer results in terms of recoveries and LODs; however, no extra solvent except IL was needed in HF-LPME, while $32 \mathrm{~mL}$ of methanol per soil sample were consumed in ATPS [88].

A common cationic surfactant (CTAB) solution [89] or an IL-based surfactant solution [90] were employed by the same research group $[89,90]$ in combination with MWE to extract PAHs, alkylphenols and a paraben from the sediment. Various parameters were optimized: temperature, concentration and volume of surfactant solution [89,90], MW power [89] and type of IL-based surfactant [90]. In the obtained filtrate, surfactant was made insoluble by the addition of an anion-exchange reagent lithium bis[(trifluoromethane)sulfonyl]imide and acetonitrile. After centrifugation, analyte-rich sedimented phase was diluted with acetonitrile to decrease viscosity and subjected to HPLC-DAD analysis. Method performance was very good in both cases [89,90], but in the method employing CTAB several interfering compounds co-extracted from the sediment and were visible in the chromatogram [89].

Matrix solid-phase dispersion (MSPD) is an extraction approach for solid samples in which sorbent and sample are blended together in a mortar; the mixture is then transferred to an empty cartridge and the analytes eluted with a suitable solvent. It was employed by Wang et al. [77] to extract pyrethroid insecticides from the soil; analytes were eluted with acetonitrile, which served as a disperser solvent in subsequent US-DLLME. Type of sorbent, sorbent/sample ratio, eluting solvent type and volume were optimized [77]. 
As seen from Table 3 and the above discussion, no details on LPME optimization are given here except where some innovative or uncommon approaches were adopted. Otherwise, optimization of DLLME, HF-LPME and SDME parameters in the above methods was the same as for aqueous samples. The obtained extracts were analyzed by GC or HPLC in all but one method [96]. In some cases, evaporation of extract and redissolution in different solvent [77,78,87], dilution [89,90] or even derivatization [82] was needed for the sake of compatibility with the analytical method.

All three types of LPME were generally reported to perform well on aqueous extracts of solid samples. Again, DLLME and its variants were the most frequently used approach [77-91], followed by HF-LPME [91-95] and SDME [96,97]. In some papers, authors compared the developed LPME procedure for the chosen analytes with another method on the basis of a more established extraction technique: SWE-SPE [82], static HS [83], HS-SPME [83], solvent extraction [98] or PLE [98]. Generally, LPME combined with environmentally-friendly sample extraction provided equally good or better results. An exception was determination of aromatic volatiles in pyrolysis leachate. Static headspace or HS-SPME provided better LODs and extracted less interfering compounds because of better specificity for volatile analytes compared to DLLME [83]. Although water or buffer solutions are generally deemed not entirely suitable to extract less polar analytes [2,3], good recoveries were reported in almost all the methods listed in Table 3. However, it has to be emphasized that the validation was usually performed only on spiked samples. In two of the published methods [93,94], authors calculated the recoveries of the method both for spiked and native samples. Recoveries in the native samples were in the range $40 \%-83 \%$ of the recoveries in spiked samples for NSAIDs extraction from sewage sludge [93], but in the same range for SSRIs extraction from the same matrix [94]. Another possible consideration against the use of water as extraction solvent would be the high probability of co-extracting several water-soluble compounds that could interfere with the analysis. This problem is avoided by subsequent LPME, which targets analytes of lower polarity. Yet, co-extracted matrix compounds could interfere with LPME as well. DLLME is more sensitive to the presence of these compounds compared to HF-LPME, in which the fiber effectively shields the solvent and prevents their extraction. In DLLME, one of the possible problems would be the failure of phases to separate after centrifugation because of the emulsifying effect of the co-extractives; in HF-LPME, high-molecular dissolved organic matter from the matrix could adsorb to the fiber and hinder the extraction. However, there are no reports of such problems in the reviewed papers. Generally, chromatograms produced in either GC or HPLC analysis following the LPME were clean and free of interferences. Only a small matrix effect, otherwise a recognized problem in LC-MS with electrospray ionization (ESI), was observed for the extracts prepared by PHWE-HF-LLLME, especially when compared to the established methods, e.g., PLE-SPE [93]. In one method, no chromatographic separation of the extract was used; the extracts obtained by DI-SDME after US extraction of the antibiotic monensin from soil with $\mathrm{NaCl}$ solution were directly analyzed by atmospheric pressurematrix-assisted laser desorption ionization mass spectrometry (AP-MALDI-MS) with very good results [96].

The above discussion and examples given within could serve as a confirmation of the suitability of water-based extraction solutions combined with LPME in the environmental analysis. The common and favorable feature of the sample preparation approaches in this category is the greatly decreased consumption of organic solvents to extract analytes from the solid samples. 
Table 4. Applications of LPME without previous extraction of solid samples.

\begin{tabular}{|c|c|c|c|c|c|c|c|c|}
\hline LPME & $\begin{array}{l}\text { Analytical } \\
\text { techn. }\end{array}$ & Sample & Analytes & $\begin{array}{l}\text { Preparation of } \\
\text { solid sample } \\
\end{array}$ & $\begin{array}{l}\text { LPME } \\
\text { procedure }\end{array}$ & $\begin{array}{l}\text { Optimization of } \\
\text { extraction conditions }\end{array}$ & $\begin{array}{l}\text { Method } \\
\text { performance }\end{array}$ & Ref. \\
\hline DLLME & GC-FPD & soil & chlorpyrifos & "soil solution" a & $\begin{array}{l}1.5 \mathrm{~mL} \mathrm{MeOH}(\mathrm{DS})+40 \mu \mathrm{L} \text { 1-dodecanol } \\
\text { (ES) inj. into } 25 \mathrm{~mL} \text { solution at } 40{ }^{\circ} \mathrm{C} \text {; } \\
\text { kept still } 5 \mathrm{~min} \text {, added } 0.5 \mathrm{~g} \mathrm{NaCl} \text {, shaken; } \\
\text { centrif.; ice bath to solidify drop, rinsed } \\
\text { with ice w., diss. in } 60 \mu \mathrm{L} \text { EtAc }\end{array}$ & $\begin{array}{l}\text { extraction solvent type \& } \\
V \text {, disperser solvent type } \\
\& V \text {, mass of } \mathrm{NaCl} \text {, extr. } \\
\text { time }\end{array}$ & $\begin{array}{l}\eta 84 \%-103 \% \text { ( } 2 \text { levels }) \\
\text { RSD }<6.4 \% \\
\text { LOD } 0.084-0.52 \mathrm{ng} / \mathrm{mL}^{\mathrm{b}}\end{array}$ & [99] \\
\hline US-DLLME & GC-MS & $\begin{array}{l}\text { house } \\
\text { dust }\end{array}$ & TBBPA & $\begin{array}{l}\text { Kimwipe sprayed } \\
\text { with } \mathrm{MeOH} / \mathrm{AC}(1: 3), \\
1 \mathrm{~min} \text { wiping of } \\
100 \mathrm{~cm}^{2} \text { area }\end{array}$ & $\begin{array}{l}1 \mathrm{~cm}^{2} \text { Kimwipe }+800 \mu \mathrm{L} \text { w. }+100 \mu \mathrm{L} \\
\mathrm{MeOH} / \mathrm{AC}(1: 3, \mathrm{DS})+30 \mu \mathrm{L} \mathrm{ClBz}(\mathrm{ES})+ \\
1 \mathrm{drop} \mathrm{HCl}_{\text {conc }}+50 \mu \mathrm{L} \text { Ac anhydride; US } \\
5 \mathrm{~min} \text {; centrif.; sedim. phase added Ac } \\
\text { anhydr., IS \& } \mathrm{CH}_{2} \mathrm{Cl}_{2} \text { to } 56 \mu \mathrm{L} \text {; US } 5 \mathrm{~min} \text {; } \\
\text { heated } 60^{\circ} \mathrm{C} \text { for } 5 \text { min, injected }\end{array}$ & $\begin{array}{l}\text { disperser solv. type } \& V \\
\text { extraction solvent type } \& \\
V \text {, swabbing material }\end{array}$ & $\begin{array}{l}\eta 104 \%-106 \% ; \mathrm{RSD}< \\
18 \% ; \text { LOD } 2.5 \mathrm{ng} / \mathrm{mL} \\
\text { compared with SPE }\end{array}$ & [100] \\
\hline HF-LPME & GC-FID & soil & 6 PAHs & $\begin{array}{l}1 \text { g s.s. }+7 \mathrm{~mL} \mathrm{AC}+ \\
15 \mathrm{~mL} \text { w.; shaking } 30 \mathrm{~s}\end{array}$ & $\begin{array}{l}22 \mathrm{~mL} \text { suspension, } 8 \mu \mathrm{L} \text { octane }(\mathrm{ES})+\mathrm{IS} \\
\text { in } 6.5 \text {-cm HF; stirring } 8 \mathrm{~min} \text { at } 1350 \mathrm{rpm} \text {; } \\
\text { direct injection }\end{array}$ & $\begin{array}{l}\text { extraction time; } \mathrm{HF} \text { : } \\
\text { stirring rate, } V_{\mathrm{AC}} \text {, extr. } \\
\text { time, } V_{\mathrm{ES}}\end{array}$ & $\begin{array}{l}\eta 2.9 \%-6.2 \%(\mathrm{PF} 80.1- \\
170.7) \\
\mathrm{RSD}<23.3 \% \\
\text { LOD } 130-220 \mathrm{ng} / \mathrm{g}\end{array}$ & [101] \\
\hline HF-LPME & HPLC-UV & soil & 2 phytohormones & none & 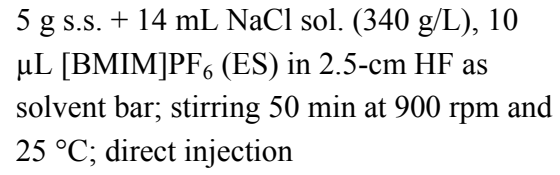 & $\begin{array}{l}V_{\text {solv }}, \text { extr. time, } T, \mathrm{NaCl} \\
\text { concentration, stirring rate }\end{array}$ & $\begin{array}{l}\eta 40 \%-60 \% ; \mathrm{RSD}<7.9 \% \\
\text { LOD } 5-30 \mathrm{ng} / \mathrm{g} ; \text { compared } \\
\text { to ATPS }\end{array}$ & {$[88]$} \\
\hline HF-LPME & GC-MS & soil & 8 triazines & $\begin{array}{l}\text { prepared slurry: } 20 \mathrm{~g} \\
\text { s.s. } / \mathrm{mL} \text { w., added } \\
\mathrm{NaCl} \text { to } 10 \%\end{array}$ & $\begin{array}{l}3 \mu \mathrm{L} \text { toluene }(\mathrm{ES}) \text { in } 1.3-\mathrm{cm} \mathrm{HF} \text { in soil } \\
\text { slurry; extr. for } 20 \mathrm{~min} \text { at } 1000 \mathrm{rpm}\end{array}$ & $\begin{array}{l}\text { extraction solvent, } \\
\text { extraction time, stirring } \\
\text { rate, addition of } \mathrm{NaCl}, \mathrm{pH} \text {, } \\
\text { humic acids }\end{array}$ & $\begin{array}{l}\eta \text { not given; RSD }<5 \% \\
\text { LOD not given; compared } \\
\text { with SDME (drop unstable) } \\
\& \text { SPME (poorer precision) }\end{array}$ & [102] \\
\hline HF-LPME & GC-MS & soil & 4 chlorophenols & $\begin{array}{l}30 \mathrm{mg} \text { s.s. }+15 \mathrm{~mL} \\
\text { w. }+ \text { IS }\end{array}$ & $\begin{array}{l}15 \mathrm{~mL} \text { suspension }+15 \mathrm{~mL} \text { pH } 1 \text { buffer } \\
\text { sol., } 15 \mu \mathrm{L} \text { 1-octanol (ES) in } 5.0 \text {-cm HF, } \\
\text { stirring } 80 \mathrm{~min} \text { at } 1100 \mathrm{rpm} \text {; direct } \\
\text { injection }\end{array}$ & $\begin{array}{l}\mathrm{pH} \& \text { ionic strength of } \\
\text { donor sol., stirring rate, } \\
\text { extraction time }\end{array}$ & $\begin{array}{l}\eta 90.52 \%-106.47 \% \text {; RSD }< \\
5.13 \% \text {; LOD not given for } \\
\text { soil; compared with SPME - } \\
\text { with HF-LPME less } \\
\text { interference }\end{array}$ & [103] \\
\hline $\begin{array}{l}\text { HF-LPME, } \\
\text { dynamic }\end{array}$ & GC-MS & soil & $\begin{array}{l}\text { methylphenols } \\
\text { chloro-benzenes, } \\
\text { chlorinated pesticides }\end{array}$ & $\begin{array}{l}1 \text { g s.s. }+4 \mathrm{~mL} \\
\text { AC/w.(40:60).; US (5 } \\
\text { min); stirring at } 1000 \\
\text { rpm (40 min) }\end{array}$ & $\begin{array}{l}4 \mathrm{~mL} \text { suspension, } 3 \mu \mathrm{L} \text { toluene (ES) in } \\
1.3-\mathrm{cm} \mathrm{HF} \text {, stirring } 4 \text { min at } 200 \mathrm{rpm} \text {, } \\
\text { dynamic extr. (syringe plunger); direct } \\
\text { injection }\end{array}$ & $\begin{array}{l}\text { type \& ratio org. solv.: w. } \\
\text { in suspension; HF: extr. } \\
\text { solvent, extr. time, plunger } \\
\text { speed, ionic strength, HA } \\
\text { conc. }\end{array}$ & $\begin{array}{l}\eta 92 \%-100 \% ; \text { RSD }< \\
13.0 \% ; \\
\text { LOD 50-100 ng/g; } \\
\text { comparison with SPME }\end{array}$ & [104] \\
\hline
\end{tabular}


Table 4. Cont.

\begin{tabular}{|c|c|c|c|c|c|c|c|c|}
\hline LPME & $\begin{array}{l}\text { Analytical } \\
\text { techn. }\end{array}$ & Sample & Analytes & $\begin{array}{l}\text { Preparation of } \\
\text { solid sample } \\
\end{array}$ & $\begin{array}{l}\text { LPME } \\
\text { procedure }\end{array}$ & $\begin{array}{l}\text { Optimization of } \\
\text { extraction conditions }\end{array}$ & $\begin{array}{l}\text { Method } \\
\text { performance }\end{array}$ & Ref. \\
\hline HF-LLLME & $\begin{array}{l}\text { LC-ESI- } \\
\text { MS }\end{array}$ & $\begin{array}{l}\text { sewage } \\
\text { sludge }\end{array}$ & SSRIs & $\begin{array}{l}0.25-1 \text { g s.s. }+50 \mathrm{~mL} \\
\text { w., pH adj. to } 12.4\end{array}$ & $\begin{array}{l}50 \mathrm{~mL} \text { suspension, DHE in } 20 \text {-cm HF wall } \\
\text { (ES) \& } 10 \mu \mathrm{L} 0.1 \mathrm{M}\left(\mathrm{NH}_{4}\right) \mathrm{H}_{2} \mathrm{PO}_{4} \mathrm{pH} 2.1 \\
\text { (AS) in } \mathrm{HF} \text { lumen; stirring } 6 \mathrm{~h} \text {; direct } \\
\text { injection }\end{array}$ & $\begin{array}{l}\mathrm{pH} \text { of sample suspension, } \\
\text { acceptor solvent \& } \mathrm{pH} \text {, } \\
\text { extraction time }\end{array}$ & $\begin{array}{l}\eta 5 \%-19 \% \text { (PF 221-995); } \\
\text { RSD }<18.4 \% \text {; LOD } 1-12 \\
\text { ng/g; comparison to HF- } \\
\text { LLLME after PHWE }\end{array}$ & {$[94]$} \\
\hline HF-LLLME & $\begin{array}{l}\text { LC-ESI- } \\
\text { MS }\end{array}$ & $\begin{array}{l}\text { sewage } \\
\text { sludge }\end{array}$ & 4 NSAIDs & $\begin{array}{l}0.5-1.5 \text { g s.s. }+50 \\
\mathrm{~mL} \text { w., stirred } 17 \mathrm{~h} \text { at } \\
660 \mathrm{rpm}, \mathrm{pH} \text { adj. to } \\
1.5\end{array}$ & $\begin{array}{l}50 \mathrm{~mL} \text { slurry, DHE in } 18 \text {-cm HF wall } \\
\text { (ES) \& } 10 \mu \mathrm{L} 0.1 \mathrm{M}\left(\mathrm{NH}_{4}\right)_{2} \mathrm{CO}_{3} \mathrm{pH} 9 \\
\text { (AS) in HF lumen; stirring } 4 \mathrm{~h} \text { at } 660 \mathrm{rpm} \text {; } \\
\text { direct injection }\end{array}$ & extraction time & $\begin{array}{l}\eta \text { not given; RSD }<17.7 \% \text {; } \\
\text { LOD not given }\end{array}$ & [105] \\
\hline $\begin{array}{l}\text { DHF-HS- } \\
\text { LPME }\end{array}$ & GC-MS & soil & 6 PAHs & $\begin{array}{l}1 \mathrm{~g} \mathrm{s.s.}+1 \mathrm{~mL} \text { w.; } \\
\text { heated at } 90{ }^{\circ} \mathrm{C} \text { for } \\
10 \mathrm{~min}\end{array}$ & $\begin{array}{l}3 \mu \mathrm{L} 1 \text {-octanol (ES) in } 1.5 \text {-cm } \mathrm{HF} \text { in } \\
\text { headspace over soil slurry heated at } 40^{\circ} \mathrm{C} \\
\text { for } 10 \text { min at } 400 \mathrm{rpm} \text {, dynamic extr. }(5 \mathrm{~s} \\
\text { dwell time); direct injection }\end{array}$ & $\begin{array}{l}\text { extraction solvent, dwell } \\
\text { time, number of cycles, } \\
\text { extraction time, } T \text {, } \\
\text { addition of w. \& } \mathrm{NaCl} \text { to } \\
\text { s.s. }\end{array}$ & $\begin{array}{l}\eta \text { not given; RSD }<14.6 \% \text {; } \\
\text { LOD } 5.9-76 \mathrm{ng} / \mathrm{g}\end{array}$ & [106] \\
\hline HS-SDME & GC-FID & $\begin{array}{l}\text { drilling } \\
\text { mud }\end{array}$ & $\mathrm{C}_{6}-\mathrm{C}_{12}$ hydrocarbons & $\begin{array}{l}\text { drilling mud with } \\
\text { water left to separate }\end{array}$ & $\begin{array}{l}5 \mathrm{~mL} \text { supernatant in vial, a drop }(1.5 \mu \mathrm{L}) \\
\text { of } n \text {-hexadecane (ES) }+ \text { IS suspended } \\
\text { from needle tip in HS; extr. for } 30 \mathrm{~min} \text { at } \\
1000 \mathrm{rpm} \text {; direct injection }\end{array}$ & $\begin{array}{l}\text { extraction solvent type } \& \\
V \text {, ionic strength of } \\
\text { sample, stirring rate, } \\
\text { extraction time }\end{array}$ & $\begin{array}{l}\text { clean chromatograms with } \\
\text { no intereferences; other data } \\
\text { not given for drilling mud }\end{array}$ & [107] \\
\hline HS-LPME & GC-ECD & soil & 5 chlorobenzenes & $\begin{array}{l}1 \mathrm{~g} \mathrm{s.s.}+1.5 \mathrm{~mL} \mathrm{w} \text {; } \\
\text { heated for } 30 \mathrm{~min} \text { at } \\
40{ }^{\circ} \mathrm{C} \text { before extr. }\end{array}$ & $\begin{array}{l}2 \mu \mathrm{L} \text { toluene }(\mathrm{ES}) \text { into } 10-\mu \mathrm{L} \\
\text { microsyringe, } 5 \mu \mathrm{L} \text { HS at } 40^{\circ} \mathrm{C} \\
\text { withdrawn at } 1 \mu \mathrm{L} / \mathrm{s} \text {, expelled, } 5 \text { s waiting, } \\
\text { repeat } 25 \text { times; direct injection }\end{array}$ & $\begin{array}{l}\text { extraction solvent type \& } \\
V, \text { HS sampling volume, } \\
\text { withdrawal rate, number } \\
\text { of cycles }\end{array}$ & $\begin{array}{l}\eta \text { not given; RSD }<17.7 \% \text {; } \\
\text { LOD } 6-14 \mathrm{ng} / \mathrm{g} \text {; compared } \\
\text { with HS-SPME }\end{array}$ & {$[44]$} \\
\hline $\begin{array}{l}\text { CF-SDME } \\
(\text { GF-HS- } \\
\left.\text { LPME }^{c}\right)\end{array}$ & GC-MS & sediment & PAHs & not given & $\begin{array}{l}\text { continuous gas flow SDME in a home- } \\
\text { designed apparatus: } \\
\text { sample heated at } 80{ }^{\circ} \mathrm{C} \text {, extr. for } 20 \mathrm{~min} \\
\text { into } 2 \mu \mathrm{L} \text { dodecane (ES) in the gas } \\
\text { channel, gas flow rate } 2.7 \mathrm{~mL} / \mathrm{min}\end{array}$ & $\begin{array}{l}\text { gas flow rate, position of } \\
\text { solvent drop, i.d. gas } \\
\text { outlet channel, extraction } \\
\text { time, sample T, extr. } \\
\text { solvent T }\end{array}$ & $\begin{array}{l}\eta \text { not given; RSD }<19.7 \% \text {; } \\
\text { LOD } 0.020-8.0 \text { ng }^{\mathrm{d}}\end{array}$ & [108] \\
\hline
\end{tabular}

${ }^{\mathrm{a}}$ no further details given on preparation; ${ }^{\mathrm{b}} \mathrm{LOD}$ given for "soil solution" only; ${ }^{\mathrm{c}}$ name proposed by authors; ${ }^{\mathrm{d}}$ LOD in ng only, sample mass not given. Abbreviations: ES extraction solvent; DS - disperser solvent in DLLME; AS — acceptor solvent in HF-LLLME; ATPS — aqueous two-phase system; DHF—dynamic hollow fiber; GF — gas flow; IS - internal standard; PF — preconcentration factor; SPE—solid-phase extraction; SPME—solid phase microextr.; s.s. - solid sample; i.d.—internal diameter. Solvents: AC—acetone; Ac—acetic; CIBz—chlorobenzene; DHE—di-n-hexyl ether; EtAc—ethyl acetate; $\mathbf{M e O H}-$ methanol; w. —water (ultrapure/double deionized/MilliQ);

[BMIm] $\mathbf{P F}_{6}$-1-butyl-3-methylimidazolium hexafluorophosphate. 


\section{LPME without Previous Extraction of Solid or Semisolid Samples}

The third category of LPME applied to solid environmental samples presented in this review are the methods of solvent microextraction directly from the solid samples with no previous extraction of analytes with either organic solvent or aqueous solution and no previous separation of the solid sample from the resulting solution. However, some simple pretreatment of the solid sample was still needed. Examples are given in Table 4.

As can readily be seen from Table 4, some minor sample preparation was still needed before the actual LPME. Usually, this just consisted of a slurry preparation from the solid sample with the addition of water $[44,88,94,102,103,105,106]$ or water-organic solvent solution $[101,104]$. The transfer of analytes into LPME organic solvent was significantly increased from the aqueous slurry compared to the dry solid sample [44]. For some analytes, addition of organic solvent into the suspension, e.g., methanol, markedly increased the recoveries [104]. Other parameters that were commonly optimized in the donor solution were ionic strength [88,102-104,106,107], $\mathrm{pH}[94,102,103]$ and temperature when LPME from the headspace was performed [44,106-108]. Yang et al. [108] developed an interesting variation of CF-SDME named gas flow headspace LPME (GF-HS-LPME). A special apparatus was designed in which an aqueous or dry sample was heated, analytes were released into the headspace and transported in a gas flow past the solvent drop positioned in a gas outlet channel. Several parameters were optimized: gas flow rate, position of solvent drop, internal diameter of the outlet channel, temperature of sample and solvent, extraction time. Method was applied to the extraction of PAHs from sediment samples, but unfortunately, no other method characteristics were given for this type of sample except precision and absolute LOD [108].

The most frequently applied mode of LPME in this category was HF-LPME [88,94,101-106], mostly with the fiber immersed directly in the suspension and with one solvent only [101-104] or with an additional acceptor solvent in the fiber lumen [94,105]. This mode of LPME is the most applicable to the aqueous slurry without the previous extraction because the fiber provides the necessary barrier to prevent the sample particles from entering the solvent. Dong et al. [88] prepared the fiber filled with ionic liquid as a solvent bar and immersed it into the suspension. Compared to ATPS, performance was slightly poorer, but the solvent (methanol) consumption was decreased from $32 \mathrm{~mL}$ to zero per sample [88]. Hou and Lee [104] employed dynamic HF-LPME from the slurry by a moving syringe plunger. Jiang et al. [106], however, performed dynamic HF-LPME to extract PAHs from the headspace over the soil slurry heated to $90{ }^{\circ} \mathrm{C}$ and got favorable results [106]. Generally, results obtained by the HF-LPME approach were satisfactory and compared well with other techniques: ATPS [88], SPME [102-104] or HF-LLLME following PHWE [94]. In the latter case, essentially the same HF-LLLME parameters were applied except for the stirring time, which was shorter with direct HF-LLLME. Both methods have shown very similar performance in terms of LOD and precision [94]. However, some problems were also reported for HF-LPME methods: clogging of the fiber pores with soil particles [101] and decreased extraction efficiency at humic acid concentration above $75 \mathrm{mg} / \mathrm{L}$ [104], although Shen and Lee [102] observed no problems at HA concentrations up to $200 \mathrm{mg} / \mathrm{L}$.

Other modes of LPME were less frequently used. One paper was found on DLLME with a solvent lighter than water, where DLLME was also applied on "soil solution" to extract the pesticide chlorpyrifos [99], but as no further details were given on the preparation of this "solution", one may as 
well speculate that it was prepared by solvent extraction and therefore the method doesn't really fall into the present category. Di Napoli-Davis and Owens [100] performed DLLME on an aqueousmethanol-acetone solution in which sorbent material used to wipe dust from electronics surfaces was sonicated. Tetrabromobisphenol-A extracted from the dust was then derivatized and determined by GC-MS. Performance of the method was compared to SPE results: DLLME method gave better precision, recoveries, and LODs [100].

Two papers on HS-SDME were found [44,107] apart from CF-SDME method already described [108]. Fang et al. [107] extracted $\mathrm{C}_{6}-\mathrm{C}_{12}$ hydrocarbons from the $\mathrm{HS}$ of various oil-derived samples, including drilling mud, which was just left to naturally separate and the liquid phase was then extracted [107]. Shen and Lee [44] extracted chlorobenzenes from soil slurry by dynamic in-syringe HS-SDME. Method was compared to HS-SPME and found to have slightly poorer recoveries and LODs [44]. Shen and Lee [102] also designed DI-SDME to extract triazines from soil slurry, but performance was poor because of an unstable solvent drop.

The reported recoveries, RSDs and LODs for the methods listed in Table 4 are generally good and comparable to methods given in Tables 2 and 3. However, most of the methods in Table 4 were developed primarily for aqueous samples and then applied to some solid sample, therefore the performance data for solid samples are often missing. This fact and a rather small number of publications dealing with this approach in the last decade hint at the possibility that it may not be the best possible from the analytical method performance point of view, although it certainly is from the environmental perspective.

\section{Conclusions}

Solvent extraction has probably been a mainstay in the isolation of various analytes from very different matrices, including environmental samples for more than a century. Research efforts in the last few decades have been directed towards diminishing its role and importance mainly due to the toxic and environmentally problematic properties of organic solvents. Several new sample preparation techniques have emerged during this time, using minimal quantities of solvents or no solvents at all. However, solvent extraction remains an important sample preparation technique in the environmental analysis of solid environmental samples because of its superior capacity to disrupt the sorption of pollutants to the solid particles and transfer them to the solution amenable to analysis. Therefore, greening efforts in this part of analytical chemistry have gone mainly in the direction of developing and testing more environmentally-friendly solvents or in the direction of miniaturization, which is the subject of the present review. Most established miniaturized liquid-phase extraction techniques are developed for aqueous matrices and the number of publications dealing with LPME applied to solid environmental samples is still very small compared to the number of papers dealing with aqueous samples. In summary, 52 publications dealing with LPME applied on the sample preparation of solid environmental samples have been found and included in this review and categorized into three different groups based on the sample preparation prior to LPME. In many of the methods reviewed in this paper, a particular LPME technique was developed, optimized and validated for aqueous samples and then - more or less marginally - applied to a solid sample. Therefore, many vital data on specific problems arising from the solid matrices, such as realistic recoveries for native samples, aging of the 
residues, interference from the solid matrices etc., are missing in the majority of the publications. Except in selected papers mentioned in the text, comparison of LPME approach to a more established extraction or clean-up methods is also missing, but would be important for the evaluation of the accuracy of the obtained results. However, there seems to be a positive trend towards introducing LPME techniques in the environmental analysis of solid samples, judging from the number of papers in the last decade. There is certainly a hope that with the number of publications, their methodological quality will also grow, contributing to the greening of yet another segment of analytical chemistry.

\section{Acknowledgments}

The author would like to acknowledge the financial support of Slovenian Research Agency, Grant P1-0153.

\section{Conflicts of Interest}

The author declares no conflict of interest.

\section{References}

1. Ramos, L. Critical overview of selected contemporary sample preparation techniques. J. Chromatogr. A 2012, 1221, 84-98.

2. Chen, Y.; Guo, Zh.; Wang, X.; Qiu, Ch. Sample preparation. J. Chromatogr. A 2008, 1184, 191-219.

3. Raynie, D.E. Modern extraction techniques. Anal. Chem. 2010, 82, 4911-4916.

4. Yazdi, A.S. Surfactant-based extraction methods. Trends Anal. Chem. 2011, 30, 918-929.

5. Rocha, D.L.; Batista, A.D.; Rocha, F.R.P.; Donati, G.L.; Nóbrega, J.A. Greening sample preparation in inorganic analysis. Trends Anal. Chem. 2013, 45, 79-92.

6. Miró, M.; Hansen, E.H. On-line sample processing involving microextraction techniques as a front-end to atomic spectrometric detection for trace metal assays: A review. Anal. Chim. Acta 2013, 782, 1-11.

7. Andruch, V.; Balogh, I.S.; Kocúrová, L.; Šandrejová, J. The present state of coupling of dispersive liquid-liquid microextraction with atomic absorption spectrometry. J. Anal. At. Spectrom. 2013, 28, 19-32.

8. Sarafraz-Yazdi, A.; Amiri, A. Liquid phase microextraction. Trends Anal. Chem. 2010, 29, 1-14.

9. Andruch, V.; Burdel, M.; Kocúrová, L.; Šandrejová, J.; Balogh, I.S. Application of ultrasonic irradiation and vortex agitation in solvent microextraction. Trends Anal. Chem. 2013, 49, 1-19.

10. Ghambarian, M.; Yamini, Y.; Esrafili, A. Developments in hollow fiber based liquid-phase microextraction: Principles and applications. Microchim. Acta 2012, 177, 271-294.

11. Mahugo-Santana, C.; Sosa-Ferrera, Z.; Torres-Padrón, M.E.; Santana-Rodríguez, J.J. Application of new approaches to liquid-phase microextraction for the determination of emerging pollutants. Trends Anal. Chem. 2011, 30, 731-748.

12. Han, D.; Row, K.H. Trends in liquid-phase microextraction, and its application to environmental and biological samples. Microchim. Acta 2012, 176, 1-22. 
13. Trujillo-Rodríguez, M.J.; Rocío-Bautista, P.; Pino, V.; Afonso, A.M. Ionic liquids in dispersive liquid-liquid microextraction. Trends Anal. Chem. 2013, 51, 87-106.

14. Herrera-Herrera, A.V.; Asensio-Ramos, M.; Hernández-Borges, J.; Rodríguez-Delgado, M.A. Dispersive liquid-liquid microextraction for determination of organic analytes. Trends Anal. Chem. 2010, 29, 728-751.

15. Chimuka, L.; Michel, M.; Cukrowska, E.; Buszewski, B. Advances in sample preparation using membrane-based liquid-phase microextraction techniques. Trends Anal. Chem. 2011, 30, 1781-1792.

16. Zgoła-Grześkowiak, A.; Grześkowiak, T. Dispersive liquid-liquid microextraction. Trends Anal. Chem. 2011, 30, 1382-1399.

17. Yan, H.; Wang, H. Recent development and applications of dispersive liquid-liquid microextraction. J. Chromatogr. A 2013, 1295, 1-15.

18. Rezaee, M.; Yamini, Y.; Faraji, M. Evolution of dispersive liquid-liquid microextraction method. J. Chromatogr. A 2010, 1217, 2342-2357.

19. Bosch Ojeda, C.; Sánchez Rojas, F. Separation and preconcentration by dispersive liquid-liquid microextraction procedure: Recent applications. Chromatographia 2011, 74, 651-679.

20. Abadi, M.D.M.; Ashraf, N.; Chamsaz, M.; Shemirani, F. An overview of liquid phase microextraction approaches combined with UV-Vis spectrophotometry. Talanta 2012, 99, 1-12.

21. Pinto, M.I.; Sontag, G.; Bernardino, R.J.; Noronha, J.P. Pesticides in water and the performance of the liquid-phase microextraction based techniques. A review. Microchem. J. 2010, 96, 225-237.

22. Jeannot, M.A.; Przyjazny, A.; Kokosa, J.M. Single drop microextraction - Development, applications and future trends. J. Chromatogr. A 2010, 1217, 2326-2336.

23. Lambropoulou, D.A.; Albanis, T.A. Liquid-phase micro-extraction techniques in pesticide residue analysis. J. Biochem. Biophys. Meth. 2007, 70, 195-228.

24. Jeannot, M.A.; Cantwell, F.F. Solvent microextraction into a single drop. Anal. Chem. 1996, 68, 2236-2240.

25. Kokosa, J.M. Advances in solvent microextraction techniques. Trends Anal. Chem. 2013, 43, 2-13.

26. Zanjani, M.R.K.; Yamini, Y.; Shariati, S.; Jönsson, J.Å. A new liquid-phase microextraction method based on solidification of floating organic drop. Anal. Chim. Acta 2007, 585, 286-293.

27. Pedersen-Bjergaard, S.; Rasmussen, K.E. Liquid-liquid-liquid microextraction for sample preparation of biological fluids prior to capillary electrophoresis. Anal. Chem. 1999, 71, 2650-2656.

28. Rasmussen, K.E.; Pedersen-Bjergaard, S.; Krogh, M.; Ugland, H.G.; Grønhaug, T. Development of a simple in-vial liquid-phase microextraction device for drug analysis compatible with capillary gas chromatography, capillary electrophoresis and high-performance liquid chromatography. J. Chromatogr. A 2000, 873, 3-11.

29. Rezaee, M.; Assadi, Y.; Hosseini, M.R.M.; Aghaee, E.; Ahmadi, F.; Berijani, S. Determination of organic compounds in water using dispersive liquid-liquid microextraction. J. Chromatogr. A 2006, 1116, 1-9.

30. Fernandes, V.C.; Subramanian, V.; Mateus, N.; Domingues, V.F.; Delerue-Matos, C. The development and optimization of a modified single-drop microextraction method for organochlorine pesticides determination by gas chromatography-tandem mass spectrometry. Microchim. Acta 2012, 178, 195-202. 
31. Ma, M.; Cantwell, F.F. Solvent microextraction with simultaneous back-extraction for sample cleanup and preconcentration: Preconcentration into a single microdrop. Anal. Chem. 1999, 71, 388-393.

32. Kocúrová, L.; Balogh, I.S.; Šandrejová, J.; Andruch, V. Recent advances in dispersive liquid-liquid microextraction using organic solvents lighter than water. A review. Microchem. J. 2012, 102, 11-17.

33. Guo, L.; Lee, H.K. Low-density solvent-based solvent demulsification dispersive liquid-liquid microextraction for the fast determination of trace levels of sixteen priority polycyclic aromatic hydrocarbons in environmental water samples. J. Chromatogr. A 2011, 1218, 5040-5046.

34. Liu, W.; Lee, H.K. Continuous-flow microextraction exceeding 1000 -fold concentration of dilute analytes. Anal. Chem. 2000, 72, 4462-4467.

35. Hansson, E.; Hakkarainen, M. Multiple headspace single-drop microextraction-a new technique for quantitative determination of styrene in polystyrene. J. Chromatogr. A 2006, 1102, 91-95.

36. Esrafili, A.; Yamini, Y.; Ghambarian, M.; Moradi, M. Dynamic three-phase hollow fiber microextraction based on two immiscible organic solvents with automated movement of the acceptor phase. J. Sep. Sci. 2011, 34, 98-106.

37. Jiang, X.; Lee, H.K. Solvent bar microextraction. Anal. Chem. 2004, 76, 5591-5596.

38. Zhang, J.; Su, T.; Lee, H.K. Development and application of microporous hollow fiber protected liquid-phase microextraction via gaseous diffusion to the determination of phenols in water. J. Chromatogr. A 2006, 1121, 10-15.

39. Anthemidis, A.N.; Mitani, C.; Balkatzopoulou, P.; Tzanavaras, P.D. On-line micro-volume introduction system developed for lower density than water extraction solvent and dispersive liquid-liquid microextraction coupled with flame atomic absorption spectrometry. Anal. Chim. Acta 2012, 733, 34-37.

40. Zhou, Q.; Bai, H.; Xie, G.; Xiao, J. Temperature-controlled ionic liquid dispersive liquid phase micro-extraction. J. Chromatogr. A 2008, 1177, 43-49.

41. Yiantzi, E.; Psillakis, E.; Tyrovola, K.; Kalogerakis, N. Vortex-assisted liquid-liquid microextraction of octylphenol, nonylphenol and bisphenol-A. Talanta 2010, 80, 2057-2062.

42. Papadopoulou, A.; Román, I.P.; Canals, A.; Tyrovola, K.; Psillakis, E. Fast screening of perfluorooctane sulfonate in water using vortex-assisted liquid-liquid microextraction coupled to liquid chromatography-mass spectrometry. Anal. Chim. Acta 2011, 691, 56-61.

43. Farajzadeh, M.A.; Afshar Mogaddam, M.R. Air-assisted liquid-liquid microextraction method as a novel microextraction technique; Application in extraction and preconcentration of phthalate esters in aqueous sample followed by gas chromatography-flame ionization detection. Anal. Chim. Acta 2012, 728, 31-38.

44. Shen, G.; Lee, H.K. Headspace liquid-phase microextraction of chlorobenzenes in soil with gas chromatography-electron capture detection. Anal. Chem. 2003, 75, 98-103.

45. Ouyang, G.; Zhao, W.; Pawliszyn, J. Automation and optimization of liquid-phase microextraction by gas chromatography. J. Chromatogr. A 2007, 1138, 47-54.

46. Esrafili, A.; Yamini, Y.; Ghambarian, M.; Moradi, M.; Seidi, S. A novel approach to automation of dynamic hollow fiber liquid-phase microextraction. J. Sep. Sci. 2011, 34, 957-964. 
47. Pedersen-Bjergaard, S.; Rasmussen, K.E. Electrokinetic migration across artificial liquid membranes. New concept for rapid sample preparation of biological fluids. J. Chromatogr. A 2006, 1109, 183-190.

48. Yamini, Y.; Seidi, S.; Rezazadeh, M. Electrical field-induced extraction and separation techniques: Promising trends in analytical chemistry - A review. Anal. Chim. Acta 2014, 814, 1-22.

49. Bello-López, M.Á.; Ramos-Payán, M.; Ocaña-González, J.A.; Fernández-Torres, R.; Callejón-Mochón, M. Analytical applications of hollow fiber liquid phase microextraction (HF-LPME): A review. Anal. Lett. 2012, 45, 804-830.

50. Nitiyanontakit, S.; Varanusupakul, P.; Miró, M. Hybrid flow analyzer for automatic hollow-fiber-assisted ionic liquid-based liquid-phase microextraction with in-line membrane regeneration. Anal. Bioanal. Chem. 2013, 405, 3279-3288.

51. Yan, X.; Yang, C.; Ren, C.; Li, D. Importance of extracting solvent vapor pressure in headspace liquid-phase microextraction. J. Chromatogr. A 2008, 1205, 182-185.

52. Zhang, J.; Lee, H.K. Headspace ionic liquid-based microdrop liquid-phase microextraction followed by microdrop thermal desorption-gas chromatographic analysis. Talanta 2010, 81, $537-542$.

53. Chisvert, A.; Román, I.P.; Vidal, L.; Canals, A. Simple and commercial readily-available approach for the direct use of ionic liquid-based single-drop microextraction prior to gas chromatography. Determination of chlorobenzenes in real water samples as model analytical application. J. Chromatogr. A 2009, 1216, 1290-1295.

54. Holopainen, S.; Nousiainen, M.; Anttalainen, O.; Sillanpää, M.E.T. Sample-extraction methods for ion-mobility spectrometry in water analysis. Trends Anal. Chem. 2012, 37, 124-134.

55. Sitko, R.; Kocot, K.; Zawisza, B.; Feist, B.; Pytlakowska, K. Liquid-phase microextraction as an attractive tool for multielement trace analysis in combination with X-ray fluorescence spectrometry: An example of simultaneous determination of $\mathrm{Fe}, \mathrm{Co}, \mathrm{Zn}, \mathrm{Ga}, \mathrm{Se}$ and $\mathrm{Pb}$ in water samples. J. Anal. At. Spectrom. 2011, 26, 1979-1985.

56. Gonzálvez, A.; Garrigues, S.; Armenta, S.; de la Guardia, M. Headspace-liquid phase microextraction for attenuated total reflection infrared determination of volatile organic compounds at trace levels. Anal. Chem. 2010, 82, 3045-3051.

57. Psillakis, E.; Kalogerakis, N. Developments in single-drop microextraction. Trends Anal. Chem. 2002, 21, 53-63.

58. Ghambarian, M.; Yamini, Y.; Esrafili, A.; Yazdanfar, N.; Moradi, M. A new concept of hollow fiber liquid-liquid-liquid microextraction compatible with gas chromatography based on two immiscible organic solvents. J. Chromatogr. A 2010, 1217, 5652-5658.

59. Melwanki, M.B.; Fuh, M.R. Dispersive liquid-liquid microextraction combined with semi-automated in-syringe back extraction as a new approach for the sample preparation of ionizable organic compounds prior to liquid chromatography. J. Chromatogr. A 2008, 1198-1199, 1-6.

60. Hu, J.; Fu, L.; Zhao, X.; Liu, X.; Wang, H.; Wang, X.; Dai, L. Dispersive liquid-liquid microextraction combined with gas chromatography-electron capture detection for the determination of polychlorinated biphenyls in soils. Anal. Chim. Acta 2009, 640, 100-105. 
61. Mudiam, M.K.R.; Ch, R.; Chauhan, A.; Manickam, N.; Jain, R.; Murthy, R.C. Optimization of UA-DLLME by experimental design methodologies for the simultaneous determination of endosulfan and its metabolites in soil and urine samples by GC-MS. Anal. Methods 2012, 4, 3855-3863.

62. Leng, G.; Lui, G.; Chen, Y.; Yin, H.; Dan, D. Vortex-assisted extraction combined with dispersive liquid-liquid microextraction for the determination of polycyclic aromatic hydrocarbons in sediment by high performance liquid chromatography. J. Sep. Sci. 2012, 35, 2796-2804.

63. Fu, L.; Liu, X.; Hu, J.; Zhao, X.; Wang, H.; Huang, C.; Wang, X. Determination of two pesticides in soils by dispersive liquid-liquid microextraction. Chromatographia 2009, 70, $1697-1701$.

64. Dong, S.; Hu, Q.; Yang, Z.; Liu, R.; Huang, G.; Huang, T. An ionic liquid-based ultrasound assisted dispersive liquid-liquid microextraction procedure followed by HPLC for the determination of low concentration of phytocides in soil. Microchem. J. 2013, 110, 221-226.

65. Asensio-Ramos, M.; Hernández-Borges, J.; Borges-Miquel, T.M.; Rodríguez-Delgado, M.Á. Ionic liquid-dispersive liquid-liquid microextraction for the simultaneous determination of pesticides and metabolites in soils using high-performance liquid chromatography and fluorescence detection. J. Chromatogr. A 2011, 1218, 4808-4816.

66. Asensio-Ramos, M.; Hernández-Borges, J.; Ravelo-Pérez, L.M.; Afonso, M.M.; Palenzuela, J.A.; Rodríguez-Delgado, M.Á. Dispersive liquid-liquid microextraction of pesticides and metabolites from soils using 1,3-dipentylimidazolium hexafluorophosphate ionic liquid as an alternative extraction solvent. Electrophoresis 2012, 33, 1449-1457.

67. Zhang, S.; Yin, X.; Yang, Q.; Wang, C.; Wang, Z. Determination of some sulfonylurea herbicides in soil by a novel liquid-phase microextraction combined with sweeping micellar electrokinetic chromatography. Anal. Bioanal. Chem. 2011, 401, 1071-1081.

68. Wu, Q.; Wang, C.; Liu, Z.; Wu, C.; Zeng, X.; Wen, J.; Wang, Z. Dispersive solid-phase extraction followed by dispersive liquid-liquid microextraction for the determination of some sulfonylurea herbicides in soil by high-performance liquid chromatography. J. Chromatogr. A 2009, 1216, 5504-5510.

69. Fontana, A.R.; Lana, N.B.; Martinez, L.D.; Altamirano, J.C. Ultrasound-assisted leaching-dispersive solid-phase extraction followed by liquid-liquid microextraction for the determination of polybrominated diphenyl ethers in sediment samples by gas chromatography-tandem mass spectrometry. Talanta 2010, 82, 359-366.

70. Lana, N.B.; Berton, P.; Covaci, A.; Atencio, A.G.; Ciocco, N.F.; Altamirano, J.C. Ultrasound leaching-dispersive liquid-liquid microextraction based on solidification of floating organic droplet for determination of polybrominated diphenyl ethers in sediment samples by gas chromatography-tandem mass spectrometry. J. Chromatogr. A 2013, 1285, 15-21.

71. Wang, X.D.; Zhao, X.N.; Liu, X.J.; Li, Y.Y.; Fu, L.Y.; Hu, J.; Huang, C.J. Homogeneous liquid-liquid extraction combined with gas chromatography-electron capture detector for the determination of three pesticide residues in soils. Anal. Chim. Acta 2008, 620, 162-169. 
72. Abdollahzadeh, Y.; Yamini, Y.; Jabbari, A.; Esrafili, A.; Rezaee, M. Application of ultrasoundassisted emulsification microextraction followed by gas chromatography for determination of organophosphorus pesticides in water and soil samples. Anal. Methods 2012, 4, 830-837.

73. Xiao, Q.; Hu, B.; Duan, J.; He, M.; Zu, W. Analysis of PBDEs in soil, dust, spiked lake water, and human serum samples by hollow fiber-liquid phasemicroextraction combined with GC-ICP-MS. J. Am. Soc. Mass Spectrom. 2007, 18, 1740-1748.

74. Lambropoulou, D.A.; Albanis, T.A. Sensitive trace enrichment of environmental antiandrogen vinclozolin from natural waters and sediment samples using hollow fiber liquid-phase microextraction. J. Chromatogr. A 2004, 1061, 11-18.

75. Asensio-Ramos, M.; Hernández-Borges, J.; González-Hernández, G.; Rodríguez-Delgado, M.Á. Hollow-fiber liquid-phase microextraction for the determination of pesticides and metabolites in soils and water samples using HPLC and fluorescence detection. Electrophoresis 2012, 33, 2184-2191.

76. Lambropoulou, D.A.; Psillakis, E.; Albanis, T.A.; Kalogerakis, N. Single-drop microextraction for the analysis of organophosphorous insecticides in water. Anal. Chim. Acta 2004, 516, 205-211.

77. Wang, H.; Yan, H.; Qiao, J. Miniaturized matrix solid-phase dispersion combined with ultrasound-assisted dispersive liquid-liquid microextraction for the determination of three pyrethroids in soil. J. Sep. Sci. 2012, 35, 292-298.

78. Wu, Q.; Li, Y.; Wang, C.; Liu, Z.; Zang, X.; Zhou, X.; Wang, Z. Dispersive liquid-liquid microextraction combined with high performance liquid chromatography-fluorescence detection for the determination of carbendazim and thiabendazole in environmental samples. Anal. Chim. Acta 2009, 638, 139-145.

79. Rezaee, M.; Yamini, Y.; Moradi, M.; Saleh, A.; Faraji, M.; Naeeni, M.H. Supercritical fluid extraction combined with dispersive liquid-liquid microextraction as a sensitive and efficient sample preparation method for determination of organic compounds in solid samples. J. Supercrit. Fluid 2010, 55, 161-168.

80. Naeeni, M.H.; Yamini, Y.; Rezaee, M. Combination of supercritical fluid extraction with dispersive liquid-liquid microextraction for extraction of organophosphorus pesticides from soil and marine sediment samples. J. Supercrit. Fluid 2011, 57, 219-226.

81. Jowkarderis, M.; Raofie, F. Optimization of supercritical fluid extraction combined with dispersive liquid-liquid microextraction as an efficient sample preparation method for determination of 4-nitrotoluene and 3-nitrotoluene in a complex matrix. Talanta 2012, 88, 50-53.

82. Wang, X.; Lin, L.; Luan, T.; Yang, L.; Tam, N.F.Y. Determination of hydroxylated metabolites of polycyclic aromatic hydrocarbons in sediment samples by combining subcritical water extraction and dispersive liquid-liquid microextraction with derivatization. Anal. Chim. Acta 2012, 753, 57-63.

83. Bernardo, M.S.; Gonçalves, M.; Lapa, N.; Barbosa, R.; Mendes, B.; Pinto, F.; Gulyurtlu, I. Determination of aromatic compounds in eluates of pyrolysis solid residues using HS-GC-MS and DLLME-GC-MS. Talanta 2009, 80, 104-108.

84. Bernardo, M.; Gonçalves, M.; Lapa, N.; Mendes, B. Determination of alkylphenols in eluates from pyrolysis solid residues using dispersive liquid-liquid microextraction. Chemosphere 2010, 79, 1026-1032. 
85. Benedé, J.L.; Chisvert, A.; Salvador, A.; Sánchez-Quiles, D.; Tovar-Sánchez, A. Determination of UV filters in both soluble and particulate fractions of seawaters by dispersive liquid-liquid microextraction followed by gas chromatography-mass spectrometry. Anal. Chim. Acta 2014, $812,50-58$.

86. Naeeni, M.H.; Yamini, Y.; Rezaee, M.; Seidi, S. Microwave-assisted extraction combined with dispersive liquid-liquid microextraction as a new approach to determination of chlorophenols in soil and sediments. J. Sep. Sci. 2012, 35, 2469-2475.

87. Wu, Q.H.; Li, Z.; Wu, C.X.; Wang, C.; Wang, Z. Application of ultrasound-assisted emulsification microextraction for the determination of triazine herbicides in soil samples by high performance liquid chromatography combined with LC-fluorescence detection. Microchim. Acta 2010, 170, 59-65.

88. Dong, S.Y.; Yang, Z.; Zhang, P.H.; Hu, Q.; Huang, T.L. Comparative study of hollow-fiber liquid-phase micro-extraction and an aqueous two-phase system for determination of phytohormones in soil. Anal. Bioanal. Chem. 2012, 403, 1743-1749.

89. Delgado, B.; Pino, V.; Ayala, J.H.; Afonso, A.M.; González, V. A novel preconcentration strategy for extraction methods based on common cationic surfactants: An alternative to classical coacervative extraction. J. Chromatogr. A 2012, 1257, 9-18.

90. Delgado, B.; Pino, V.; Anderson, J.L.; Ayala, J.H.; Afonso, A.M.; González, V. An in-situ extraction-preconcentration method using ionic liquid-based surfactants for the determination of organic contaminants contained in marine sediments. Talanta 2012, 99, 972-983.

91. Xiong, J.; Hu, B. Comparison of hollow fiber liquid phase microextraction and dispersive liquid-liquid microextraction for the determination of organosulfur pesticides in environmental and beverage samples by gas chromatography with flame photometric detection. J. Chromatogr. A 2008, 1193, 7-18.

92. Basheer, C.; Obbard, J.P.; Lee, H.K. Analysis of persistent organic pollutants in marine sediments using a novel microwave assisted solvent extraction and liquid-phase microextraction technique. J. Chromatogr. A 2005, 1068, 221-228.

93. Saleh, A.; Larsson, E.; Yamini, Y.; Jönsson, J.Å. Hollow fiber liquid phase microextraction as a preconcentration and clean-up step after pressurized hot water extraction for the determination of non-steroidal anti-inflammatory drugs in sewage sludge. J. Chromatogr. A 2011, 1218, 1331-1339.

94. Sagristà, E.; Cortés, J.M.; Larsson, E.; Salvadó, V.; Hidalgo, M.; Jönsson, J.Å. Comparison of two extraction methods for the determination of selective serotonin reuptake inhibitors in sewage sludge by hollow fiber liquid-phase microextraction. J. Sep. Sci. 2012, 35, 2460-2468.

95. Vasskog, T.; Bergersen, O.; Anderssen, T.; Jensen, E.; Eggen, T. Depletion of selective serotonin reuptake inhibitors during sewage sludge composting. Waste Managem. 2009, 29, 2808-2815.

96. Sekar, R.; Wu, H.F. Quantitative method for analysis of monensin in soil, water, and urine by direct combination of single-drop microextraction with atmospheric pressure matrix-assisted laser desorption/ionization mass spectrometry. Anal. Chem. 2006, 78, 6306-6313.

97. Sanagi, M.M.; Basri, R.S.; Miskam, M.; Ibrahim, W.A.W.; Ahmad, U.K.; Aboul-Enein, H.Y. Headspace single drop microextraction for the analysis of fire accelerants in fire debris samples. Anal. Lett. 2010, 43, 2257-2266. 
98. Barri, T.; Bergström, S.; Hussen, A.; Norberg, J.; Jönsson, J.Å. Extracting syringe for determination of organochlorine pesticides in leachate water and soil-water slurry: A novel technology for environmental analysis. J. Chromatogr. A 2006, 1111, 11-20.

99. Xiong, J.; Guan, Z.; Zhou, G.; Tang, X.; Lv, Y.; Wang, H. Determination of chlorpyrifos in environmental water samples by dispersive liquid-liquid microextraction with solidification of a floating organic drop followed by gas chromatography with flame photometry detection. Anal. Methods 2012, 4, 3246-3250.

100. Di Napoli-Davis, G.; Owens, J.E. Quantitation of tetrabromobisphenol-A from dust sampled on consumer electronics by dispersed liquid-liquid microextraction. Environ. Pollut. 2013, 180, 274-280.

101. King, S.; Meyer, J.S.; Andrews, A.R.J. Screening method for polycyclic aromatic hydrocarbons in soil using hollow fiber membrane solvent microextraction. J. Chromatogr. A 2002, 982, 201-208.

102. Shen, G.; Lee, H.K. Hollow fiber-protected liquid-phase microextraction of triazine herbicides. Anal. Chem. 2002, 74, 648-654.

103. Chung, L.W.; Lee, M.R. Evaluation of liquid-phase microextraction conditions for determination of chlorophenols in environmental samples using gas chromatography-mass spectrometry without derivatization. Talanta 2008, 76, 154-160.

104. Hou, L.; Lee, H.K. Determination of pesticides in soil by liquid phase microextraction and gas chromatography-mass spectrometry. J. Chromatogr. A 2004, 1038, 37-42.

105. Sagristà, E.; Larsson, E.; Ezoddin, M.; Hidalgo, M.; Salvadó, V.; Jönsson, J.Å. Determination of non-steroidal anti-inflammatory drugs in sewage sludge by direct hollow fiber supported liquid membrane extraction and liquid chromatography-mass spectrometry. J. Chromatogr. A 2010, 1217, 6153-6158.

106. Jiang, X.; Basheer, C.; Zhang, J.; Lee, H.K. Dynamic hollow fiber-supported headspace liquid-phase microextraction. J. Chromatogr. A 2005, 1087, 289-294.

107. Fang, C.; Xiong, Y.; Liang, Q.; Li, Y.; Peng, P. Optimization of headspace single-drop microextraction technique for extraction of light hydrocarbons $\left(\mathrm{C}_{6}-\mathrm{C}_{12}\right)$ and its potential applications. Org. Geochem. 2011, 42, 316-322.

108. Yang, C.; Qiu, J.; Ren, C.; Piao, X.; Li, X.; Wu, X.; Li, D. Gas flow headspace liquid phase microextraction. J. Chromatogr. A 2009, 1216, 7694-7599.

(C) 2014 by the authors; licensee MDPI, Basel, Switzerland. This article is an open access article distributed under the terms and conditions of the Creative Commons Attribution license (http://creativecommons.org/licenses/by/3.0/). 